\title{
Volatile Top Income Shares in Switzerland? Reassessing the Evolution Between 1981 and 2010*
}

\author{
Forthcoming The Review of Economics and Statistics \\ Reto Foellmi ${ }^{\dagger} \quad$ Isabel Z. Martínez ${ }^{\ddagger}$
}

July 28,2016

\begin{abstract}
In the last 20 years, the share of top incomes in Switzerland has risen, while exhibiting large variations. Switzerland is similar to European countries for the top $1 \%$ but closer to the U.S. for higher top income groups. With the synthetic control method we close a time gap in the tax data, exploiting the fact that Swiss cantons changed their tax system at different points in time. Using social security data which cover all top labor incomes, we document the growing importance of labor compared to capital incomes among top income earners in Switzerland.
\end{abstract}

JEL Classification: D31, H24, C81 and N33

${ }^{*}$ We thank Facundo Alvaredo, Salvatore Babones, Monika Bütler, Stephen Jenkins, Thomas Piketty, Emmanuel Saez, Lukas Schmid, and two anonymous referees, whose suggestions greatly improved the paper, as well as numerous conference participants for helpful comments and discussions. We thank Roger Ammann from the Federal Tax Administration in Bern, as well as David Sánchez and Hans-Peter Naef from the Central Compensation Office CCO-ZAS in Geneva for making the data needed for this project available. Special thanks go to Raphaël Parchet, University of Lugano, for compiling the tax statistics. Timo Daehler provided excellent assistance preparing the manuscript for publication. This project was supported by the SNF Sinergia grant CRSI11-132272 "Economic Inequality and International Trade". The individual income tax data used in parts of this study have been made available by the Federal Tax Administration in Bern through the SNF Sinergia grant 130648 "The Swiss Confederation: A Natural Laboratory for Research on Fiscal and Political Decentralization".

${ }^{\dagger}$ University of St. Gallen, Bodanstrasse 8, CH-9000 St. Gallen, Switzerland, E-mail: reto.foellmi@unisg.ch, Phone: +41 712242269.

$\ddagger$ University of St. Gallen, Bodanstrasse 8, CH-9000 St. Gallen, Switzerland, E-mail: isabel.martinez@unisg.ch, Phone: +4171224 3161. 


\section{Introduction}

The evolution of inequality in income and wealth has again attracted substantial attention in recent decades. In the aftermath of the financial crisis, distributional issues have been discussed even more intensely, trying to capture the relation between distribution and growth patterns. In line with public interest, the academic focus has been notably on the top of the income distribution, in particular because changes in the very top incomes account for a large part of overall inequality in quantitative terms.

The present paper studies the evolution of top incomes in Switzerland. The Swiss data are of interest because it is a major industrialized country with a large financial sector. Tax competition within Switzerland and the absence of wars have kept tax rates low and have not foreclosed possible wealth accumulation by rich households, unlike its European neighbors. Swiss top incomes are also worth studying because the Swiss social security system (AHV) has no upper income limit, which is different from most other industrialized countries. Hence, the AHV data cover all labor incomes, which makes it possible to study the evolution of top labor incomes and to compare their dynamics with the dynamics of overall top incomes.

The seminal study by Thomas Piketty (2001) on the evolution of top incomes in France using tax data, covering the time span from 1901 to 1998, found broad interest and was followed by a range of similar studies on other countries. Internationally, top deciles and percentiles have experienced considerable changes in their total income shares during the 20th century. Until the end of World War II, most countries experienced a sharp drop in top income shares. For the second half of the 20th century, a ' $U$ ' shaped evolution can be observed, yet this varies considerably across countries. The continental European countries - including Switzerland - and Japan experienced almost no or only a modest increase in top income shares from the 1970s onward, while there was a remarkably strong increase in Western English speaking countries (Atkinson et al., 2011). Atkinson and Piketty $(2007,2010)$ provide a collection of these studies. Dell et al. (2007) study top incomes in Switzerland. The data used in their study reach back into the 1930s. Unfortunately, the tax data end in 1995/1996 when a major reform in the Swiss tax 
system took place. As described in Section 2, not all cantons adopted the changes at one and the same time, resulting in a lack of uniform data for the whole country for the transition period 1995-2002.

The first contribution of this paper is to close this large data gap. We make use of a novel approach to estimate missing data and describe top incomes in a period which delineates a break with the former decades of steady growth rates and full employment. In the 1990s, Switzerland experienced a decade of very low growth and a remarkable increase in the unemployment rate from $1.8 \%$ in 1991 to $4.3 \%$ in 1997 , accompanied by ongoing immigration. As tax data are available at the cantonal level for every year, including the transition period, we can estimate in Section 3 the distribution of taxable income in the missing years and extend the series up to 2010, the latest year for which tax statistics are available so far. ${ }^{1}$ Concerning methods, we apply the synthetic control method of Abadie et al. (2010) for a new purpose: to construct aggregate time series when the underlying time series of the subgroups have missing values.

Our second contribution is the use of income data from the AHV statistics to estimate the distribution of (top) labor earnings in Switzerland, covering the period from 1981 to 2010. Our results suggest that the increase in top labor incomes is instrumental in explaining the rise in top total incomes, as the latter follow the former closely. The AHV data have the additional advantage that the individual values are available, which allows calculating the top quantiles precisely and judging the accuracy of the Pareto approximation widely used in the study of top incomes. The results show how precise this method is indeed in estimating top income shares.

The remainder of the paper is organized as follows. Section 2 gives a short introduction to the Swiss tax system and describes the data used to estimate the top income shares in Section 3. Section 4 presents the results on top income shares for total incomes. The role of labor incomes at the top is assessed in Section 5 along with estimates of the concentration of wealth. Section 6 concludes.

\footnotetext{
${ }^{1}$ Schaltegger and Gorgas (2011) investigate the evolution of top incomes at a cantonal (i.e., state) level and the possible effects of different tax strategies adopted by the 26 Swiss cantons. The change in the tax system and the problem of missing data for the seven-year transition period is not addressed in their study.
} 


\section{Data and Methodology}

\subsection{On the Use of Tax Data for Economic Research}

The study of Piketty (2001) on top income shares in France in the long run initiated a new wave of research on the dynamics of top incomes in different countries (for a collection of these studies see Atkinson and Piketty, 2007, 2010). The crucial innovation compared to earlier studies on income distribution is the use of long time series going back to the beginning of the twentieth century. This is an important feature as "structural changes in income and wealth distribution often span several decades." (Piketty and Saez, 2006, p.200). To study long time periods, tax data are the only reliable data available, as household income surveys did not exist for a long time, differ in frequency or suffer from incomparability, and fail to capture the whole income distribution. Tax data have the advantage that they cover a much larger population sample than household survey data, in some cases, the entire population.

The use of tax data, however, does not come without drawbacks. The main concern is misreporting of income, as there are incentives for tax evasion to do so. With a progressive tax system in place, misreporting and tax evasion is more attractive for higher incomes. However, when using data from household surveys, one should also be concerned about non-response, sampling errors, and top-coded incomes. These problems particularly affect top income earners (see for example Brewer et al., 2008 for the UK, and Burkhauser et al., 2012 for the U.S; on the peculiarities of survey data in general, see VictoriaFeser, 2000, and Diekmann, 2004). When turning to the estimation of top income shares and inequality measures, these disadvantages lead to erroneous results. For the U.S., Atkinson et al. (2011) estimate that CPS survey data fail to capture about one half of the overall increase in inequality measured by the Gini coefficient, confirming previous results by Alvaredo (2011). The latter further shows that the Gini coefficient estimated with income survey data not only underestimates the changes in income inequality when compared to the one estimated with tax data, but the trends in inequality measured by Gini coefficients may even diverge, as is the case for Argentina. 
The second disadvantage of tax data often mentioned is its definition of income. As the data are collected as part of an administrative process, the definitions of income and income units are not tailored to their corresponding definitions in economic theory and practice. This also implies that substantial changes in the tax law, such as income splitting for married couples, have to be taken into account when attempting to construct homogeneous time series. The concrete limitations emerging from the definition of income imposed by the tax system in Switzerland are discussed in the next section.

\subsection{The Swiss Tax System Over Time}

In Switzerland, personal income taxes are levied at the federal, the cantonal, and the municipal level. Cantons are responsible for the tax collection at all three levels. For what follows, however, only the federal income tax system and data are of relevance.

In the mid-1990s, a fundamental change in the Swiss tax system took place by switching from the two-years based praenumerando taxation to the one-year based postnumerando taxation. ${ }^{2}$ The phrase "praenumerando method" refers to the fact that the assessment period and the fiscal period do not coincide under such a tax system: the assessment period precedes the fiscal period (Eidgenössische Steuerverwaltung ESTV, 2003). The tax liability for a fiscal period was thus calculated from an estimated income stream based upon past income, and taxes were only adapted to a new income situation or changed living conditions (marriage, birth of a child, etc.) in the next fiscal period. In order to adapt to significant changes in taxable income, often a betwixt assessment (called Zwischenveranlagung) became necessary.

In 1990, the change to the postnumerando taxation with a one-year assessment basis was enacted, yet allowing for a transition period of several years, during which each canton could choose when to adopt the new system. For this reason there is no uniform tax data published at the federal level during the transitional period from 1995 to 2002, as only data at the cantonal level is available. Table C.1 in Appendix C shows the time schedule of the adoption of the new taxation method by canton. Basel-Stadt was the

\footnotetext{
${ }^{2}$ The difference between the two taxation principles and the steps of the reform are described in detail in Appendix C.
} 
only canton which had always used the one-year based postnumerando taxation method to levy its cantonal taxes. All other cantons had to adapt their tax systems.

The transition caused a gap in the assessment of incomes and taxes. The following example for Zurich shows the nature of this gap. Under praenumerando taxation, incomes realized in the 1995/96 assessment period are recorded and published in the 1997/98 fiscal period. The crucial difference to the postnumerando taxation is that under the latter the assessment period equals the fiscal period, so that for the fiscal periods 1999 and 2000, when the new system was in place, the tax base was the income earned in 1999 and 2000, respectively. This implies that income realized in 1997/98 was never taxed and does not show up in any statistics. To avoid loopholes in the tax system, transitory provisions had been enacted, but these differed among cantons. ${ }^{3}$ Table 1 below illustrates the transition for a fictitious tax unit.

Table 1: Overview over praenumerando and postnumerando taxation

\begin{tabular}{|c|c|c|c|c|c|c|}
\hline Year $\mathrm{x}$ & 1995 & 1996 & 1997 & 1998 & 1999 & 2000 \\
\hline Realized income & 100,000 & 105,000 & 110,000 & 115,000 & 120,000 & 125,000 \\
\hline $\begin{array}{l}\text { Tax base for the } \\
\text { assessment period } \mathrm{x}\end{array}$ & $\begin{array}{r}\text { [incomes } \\
1993 \text { a }\end{array}$ & $\begin{array}{l}\text { ealized in } \\
\text { d 1994] }\end{array}$ & $\begin{array}{r}100000 \\
=102\end{array}$ & $\frac{+105000}{\frac{+20}{500 \text { p.a. }}}$ & 120,000 & 125,000 \\
\hline $\begin{array}{l}\text { Payment of the tax } \\
\text { liability for year } \mathrm{x}\end{array}$ & $\begin{array}{r}\mathrm{d} u \\
1995 \text { ? }\end{array}$ & $\begin{array}{l}\text { ing } \\
\text { dd } 1996\end{array}$ & $\begin{array}{r}\text { dur } \\
1997 \text { al }\end{array}$ & $\begin{array}{l}\text { ring } \\
\text { nd } 1998\end{array}$ & $\begin{array}{l}\text { beginning } \\
2000\end{array}$ & $\begin{array}{l}\text { beginning } \\
2001\end{array}$ \\
\hline
\end{tabular}

Note: The table exemplarily shows the transition from the prae- to the postnumerando taxation in the case of a hypothetical taxpayer.

\subsection{The Swiss Tax Statistics}

\subsubsection{The Grouped Tax Data}

The Swiss tax statistics are published in grouped form according to income brackets containing the total number of tax units and total income within each bracket. ${ }^{4}$ The

\footnotetext{
${ }^{3}$ For further information on these transitory provisions see Eidgenössiche Steuerverwaltung ESTV (2003).

${ }^{4}$ Available from the Federal Tax Administration Eidgenössische Steuerverwaltung (ESTV), www.estv.admin.ch
} 
cantons are the administrative unit in charge of the collection of the tax returns and the taxes. This mechanism ensures that information on incomes is available at the cantonal and federal levels at the same time and in the same format. The definitions of tax units and incomes tabulated in the tax statistics have remained fairly stable over time, allowing comparisons over time and between cantons. ${ }^{5}$

However, the change from praenumerando to postnumerando taxation had one substantial impact on the tax statistics. The years indicated in these statistics refer to the fiscal period, which means that under the praenumerando method, reported incomes were realized in the two preceding years, but after the change, the reported incomes were realized in the year reported. As a consequence, data on realized incomes is missing for the period preceding the change.

With respect to inequality measures and top income shares, the change from the biennial to the annual tax schedule would be expected to make a difference, due to the averaging effect of the biennial tax assessment. Yearly fluctuations in earned income, which alter the measured inequality of a distribution, are dampened when income is measured only once every two years.

\subsubsection{Tax Units Covered in the Statistics}

Every permanent resident in Switzerland who has completed the age of 18 years (20 years prior to $1996^{6}$ ) is subject to income taxation and has to fill out a tax return every year (every second year before the reform). To include all tax units filing a tax return, the "normal cases" (Normalfälle) as well as the "special cases" (Sonderfälle) must be considered. ${ }^{7}$ The latter not only include cases where a betwixt assessment was necessary (see Section 2.2), but also high net wealth individuals taxed according to their expenditures (Besteuerung nach dem Aufwand) and are thus highly relevant in the top income groups. ${ }^{8}$

\footnotetext{
${ }^{5}$ In recent years, officially published tabulations have been less detailed, with a top income bracket of only CHF 200,000 and excluding the "special cases" (Sonderfälle). However, more detailed tabulations, as used in the present study, are still available upon request from the Federal Tax Administration.

${ }^{6}$ Art. $14 \mathrm{ZGB}$

${ }^{7}$ Schaltegger and Gorgas (2011) include normal cases only from 1971 onwards, so our results are not directly comparable to theirs.

${ }^{8}$ See Appendix C for further details.
} 
Married and officially registered couples are subject to joint tax liability and show up as one single unit in the tax statistics. This means that a tax unit is not always an individual nor does it necessarily correspond to the concept of a household.

Even though according to the definition above every permanent resident is subject to income taxation, the rate of filers covered is below 100\%. There are, namely, three different groups of individuals not covered in the statistics. The first group consists of those whose taxable income was not high enough to surpass the amount of exemption. Thus, even though tax units with no or very little incomes have to hand in a tax return, they do not show up in the statistics if their tax liability is zero. As the purpose of the present paper is to study incomes at the top, this is only a minor problem. The second group not covered in the statistics are individuals taxed at the source. These are foreign nationals living in Switzerland but with only a temporary resident permit. Only when their income exceeds a certain threshold (around CHF 120,000 in 2012) are they required to file a tax return ex post, which ensures that top earners are nevertheless included in the statistics. The third special category of residents are staff of international organizations based in Switzerland, who are exempted totally or partially from personal income taxation. This applies to no less than 24 organizations, 22 of them located in Geneva. These individuals as well as their incomes are therefore not covered in the statistics.

It is important to note that, apart from these three groups which do not show up in the statistics due to their special legal status or low income, people who simply do not hand in their tax return, even though they are required to do so, i.e., "true non-filers," do show up in the statistics. ${ }^{9}$ In such cases, cantonal tax administrations simply attribute to these individuals an income based on older tax returns and on employers' information about their income. True non-filers are then taxed according to this imputed income without any deductions and are in addition subject to a fine.

\footnotetext{
${ }^{9}$ The Canada Revenue Agency gives the following definition: "A non-filer is an individual, a corporation, or a trust who fails to file a tax return as required by legislation." (http://www.oag-bvg.gc.ca) This is what we refer to as "true non-filers."
} 


\subsubsection{Definition of Income}

All incomes from employment and self-employment as well as capital income and transfer payments such as old age pensions are subject to the personal income tax. House owners living in their own house in addition have to report the value of an imputed rent (the so-called Eigenmietwert). Realized capital gains on private assets on the other hand are excluded from the definition of income. Overall, no distinction between labor and capital income is made. This implies some limitations for analyses carried out with the Swiss tax data for, as Piketty and Saez (2006, p. 200) state, economic mechanisms can be very different for the distribution of labor and capital income. We try to circumvent this limitation with the analysis of top labor incomes using social security data in Section 5.

Expenditures related to the realization of income, as well as health insurance premia and mortgage interest payments, are subject to deductions. As the tax liability for a married or officially registered couple is calculated on their combined income, these taxpayers can further claim a deduction if both contribute to the household's income. Additional deductions can be made for children and other dependents living with the family. Our series are based on Reineinkommen ${ }^{10}$ reported in the tax statistics. This corresponds more or less to some notion of "gross income" after itemized deductions but before personal deductions (Sozialabzüge). Most importantly, this income definition has remained stable over time and is the same top shares in Dell et al. (2007) are based on.

\subsection{Total Income Denominator and Total Tax Units}

Because not all tax units residing in the country are covered in the statistics, the same is true for the totality of incomes earned in a given period. The extent of underestimated total income in the tax statistics can be assessed by relating the total of declared incomes to an exogenous measure of total income in the economy, such as net national income reported in the national accounts. The ratio of reported tax income to the net national income starts at around $72 \%$ in 1981 but then falls over time to a low of $60 \%$ in 2006, rising

\footnotetext{
${ }^{10}$ Reineinkommen or revenu net, the nomenclature used by the Swiss statistical publications, literally means "pure" or "net" income. For detailed information, see the tax statistics' appendix with explanations: http://www.estv.admin.ch/dokumentation/00075/00076/00701/
} 
again afterwards. It is thus necessary to accurately estimate total personal income, which is then used as the denominator to calculate the top group's income shares. We closely follow the approach adopted by Dell et al. (2007), assigning the tax units not covered in the statistics $20 \%$ of average personal income reported in the tax statistics (i.e., $20 \%$ of the average Reineinkommen). This reasonable assumption further guarantees a high level of comparability with the existing series, so that our update should not cause a break in the series. See Appendix C for further details.

The income denominator containing the imputed incomes for non-filers fluctuates somewhere between $65 \%$ and $74 \%$. These results are in line with those reported by Dell et al. (2007). This remaining gap can at least partly be explained by tax evasion, which according to a study by Feld and Frey (2006) varies between 12.6\% in 1978 and $35.1 \%$ in 1990, and lies somewhat above $20 \%$ on average. There are also considerable cantonal differences which change from year to year (between 1970 and 1995). The average across all cantons in 1995 is $22.3 \%$. However, we have reason to believe that the behavioral patterns of tax evasion remained relatively stable among the top groups over time (see discussion in Section 4.2.2).

To accurately calculate the percentage shares of the top income groups, the same argument as for the total income applies: as not all tax units are contained in the tax statistics, it is necessary to calculate the total tax units in the country. Formally, the total number of tax units consists of the adult population minus one half of the married adult population. We construct this number using register data, which is available on a yearly basis at the federal as well as at the cantonal level for the time span considered in the present study. ${ }^{11}$

We follow the same approaches to construct the number of total tax units and the total income denominators at the cantonal level. Only the number of married adults at the cantonal level is interpolated linearly, as data on married adults is not available on a yearly basis.

\footnotetext{
${ }^{11}$ This approach differs slightly from the one adopted by Dell et al. (2007), who use decennial census data and linear interpolation for the years in between. See Appendix C for further details.
} 


\section{Estimating Top Income Shares in Switzerland from}

\section{$1981 / 82$ to 2010}

\subsection{Pareto Interpolation}

Since tax data are given in absolute income brackets, the income of a given quantile must be estimated by falling back on parametric assumptions about the income distribution. There is ample empirical evidence that incomes at the top of the distribution are approximately Pareto distributed. ${ }^{12}$

Assuming that incomes are Pareto distributed, the cumulative distribution function $F(s)$ is given by

$$
1-F(s)=(k / s)^{a} \quad \text { with } k>0, a>1, \text { and } s \geq k
$$

where the parameters $a$ and $k$ have to be estimated. Consequently, the probability density function takes the form $f(s)=a k^{a} / s^{a+1}$. As $f(z \mid z \geq s)=f(z) /(1-F(s))$, the average income $\bar{y}(s)$ of tax units with income larger than or equal to $s$ is given by

$$
\bar{y}(s)=\int_{s}^{\infty} z \cdot f((z \mid z \geq s)) d z=\frac{a}{a-1} \cdot s
$$

This is a central characteristic of the Pareto distribution: expected income above a given threshold $s$ is a factor $b=a /(a-1)$ times the threshold $s$; the factor is constant and independent of the threshold $s$ itself. It is possible to estimate the parameter $a$ if one knows the number of tax units above a given threshold $s$ and their average income $\bar{y}(s)$.

To estimate the top shares, we follow the approach suggested by Piketty (2001) and adopted by Dell et al. (2007) in their study on top income shares in Switzerland from 1933 onward, thus guaranteeing comparability of the series. Using the local Pareto distribution

\footnotetext{
${ }^{12}$ Gabaix (2009) presents theoretical motivations for the emergence of a Pareto distribution at the top for income and wealth. In the context of CEO pay, Gabaix and Landier (2008) present a model where matching, combined with extreme value theory for the initial firm size and the distribution of talent among CEOs, can explain the emergence of a power law. For an overview of popular variants of Pareto's models, the reader is referred to Arnold (2008).
} 
parameters $a$ and $k$ within a given income bracket, the income thresholds to belong to a certain top group, and their average and total incomes are estimated. The latter is used to calculate the share in total income for the corresponding top group. Details on the estimation procedure are outlined in Appendix C.

\subsection{Cantonal Top Shares}

For the years where data at the federal level is missing, we estimate the national income shares using cantonal top shares, based on federal income tax statistics at the cantonal level. The latter are available throughout the reform period with the exception of the two years before the change to the praenumerando method.

Figure 1 shows the income shares for the top $1 \%$ group in Switzerland and several cantons from 1981/82 to 2008. Cantons which changed their tax system on the same date are pooled together (these are Zurich and Thurgau (ZH, TG); Vaud, Valais and Ticino (VD, VS, TI); Basel-Stadt (BS); and the group of the remaining 20 cantons). So instead of speaking of cantonal series, what follows is based upon series for geographical areas that do not need to comprise only one canton. An advantage of these aggregated series is that they are less sensitive to both changes in the composition of the underlying population and to idiosyncratic changes of individual top incomes. Note how Basel-Stadt, a small canton in terms of population, exhibits higher volatility in top income shares.

In the years for which national data are available, the cantons reveal similar trends as trends at the national level. Note that the top shares within the cantons correspond to total cantonal income, i.e., to the income distribution within each canton. So even though the Swiss distribution clearly depends on the distribution within each canton, the Swiss top shares cannot be obtained by simply averaging cantonal top shares. ${ }^{13}$ The next step is to accurately estimate the values for these missing years.

\footnotetext{
${ }^{13}$ In their study of cantonal top shares, Schaltegger and Gorgas (2011) fill the gap in the data by averaging incomes over two years from the yearly tabulations ex post. This however, is not equivalent to the tabulations in the old system, as averaging income brackets over two years does not take into account any individual income mobility across brackets. Such averaging will therefore potentially decrease the estimated inequality at the top even more than the biennial assessment of incomes does.
} 


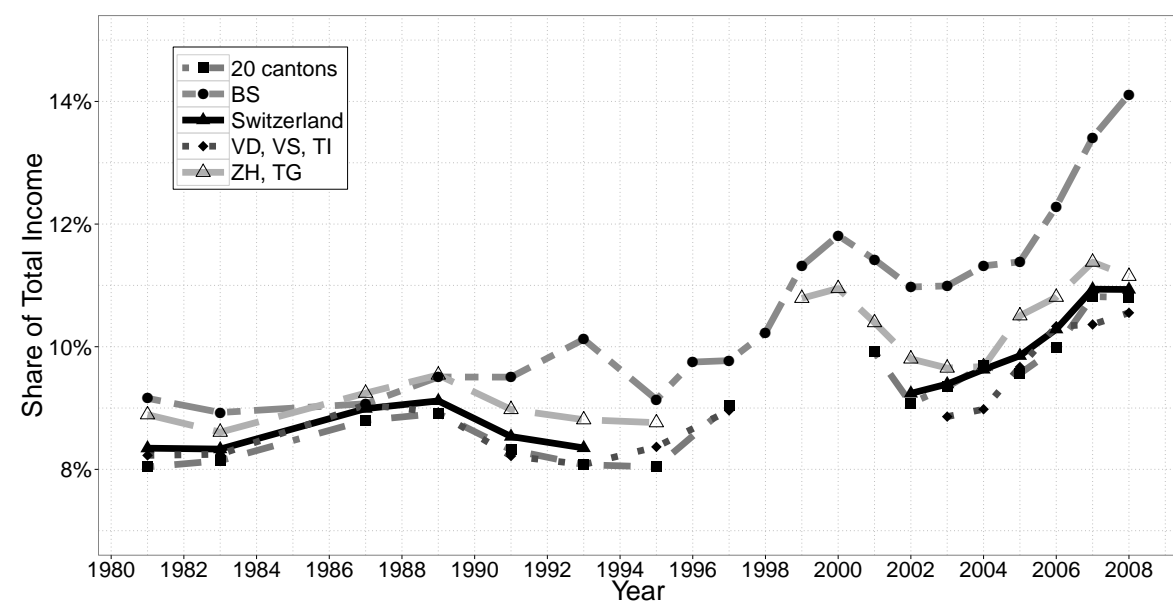

Figure 1: Top 1\% income shares for Switzerland and grouped cantons

Note: Top income shares for different cantons, grouped into "regions" according to the point in time when cantons changed from prae- to postnumerando taxation. The underlying tax statistics were first aggregated at this "regional" level before the corresponding top income shares were computed using the Pareto interpolation method. Source: Federal income tax statistics, own calculations.

\subsection{Estimating top income shares for the transition period}

Figure 1 reveals the structure of the data we use for the estimation of the missing years at the national level. We consider three methods to fill the gap from 1995 to 2002: (i) imputation, (ii) OLS regression, and (iii) synthetic control.

The first method exploits the variation in top shares using only the available cantons and excluding the cantons for which data are missing in a given year ('imputation'). Comparing this value to the value when including all cantons shows the influence of the excluded canton on the Swiss series, and the variation can then be used to impute the missing years. As the gap is ten years and different cantons are available in different years, the imputation is done in a consecutive way and based on different cantonal series.

Second, we use OLS with cantonal fixed effects to estimate the relation between the national and cantonal top income shares for the years 1981-2008. Using linear forecasting (i.e., using the estimated coefficients), the missing values for the Swiss series are estimated from the cantonal series. For each year, we regress the series for Switzerland on the maximum number of cantons available. Table C.2 in Appendix C shows the different models estimated for each year. The last row indicates the years for which each model was used to obtain the predicted values. 
An alternative to the previous two techniques is the synthetic control method of Abadie et al. (2010). Their original motivation for the use of synthetic controls was to estimate the effect of a policy change in one region compared to the absence of the policy. The idea is to compare the evolution of an outcome variable in the affected region to its hypothetical evolution if the policy intervention had not taken place. Instead of just comparing the region of interest to a similar control region, the synthetic control region is constructed out of a whole set of potential control regions (for more details see Abadie and Gardeazabal, 2003; Abadie et al., 2010, 2015; Bechtel et al., 2016). Similar to the analysis of the evolution of an outcome variable after a policy change, here the question is: what would we have observed if we had the tax data for Switzerland as a whole? The predicting variables used are all top groups' income shares, the corresponding income thresholds to belong to a top group, and the average income above a threshold. In addition, GDP and population growth rates, GDP per capita, and the unemployment rate are included. For details on the predictors and weights used, see Tables B.1 and B.2 in Appendix B.

The synthetic control method exhibits the theoretical advantage that the implied weights of the sub-groups (in our case the cantons) must be between 0 and 1 . With OLS or imputation, this is not guaranteed (see Abadie et al., 2015). Empirically, the synthetic control method has the advantage that the estimated time series has a lower volatility than the one derived from the other methods. Furthermore the estimated income series fits the labor incomes series, which are available in all years, better. The results throughout the paper are therefore based on the synthetic control method. We discuss the (small) numerical differences between the three imputation methods in Subsection 4.2.1 below.

\title{
4 Results: Top Income Shares in Switzerland
}

\subsection{The Evolution Between 1981/82 and 2010}

\author{
Main Finding: An Upward Trend
}

Figure 2 shows that the share of income going to the top income earners increased from 


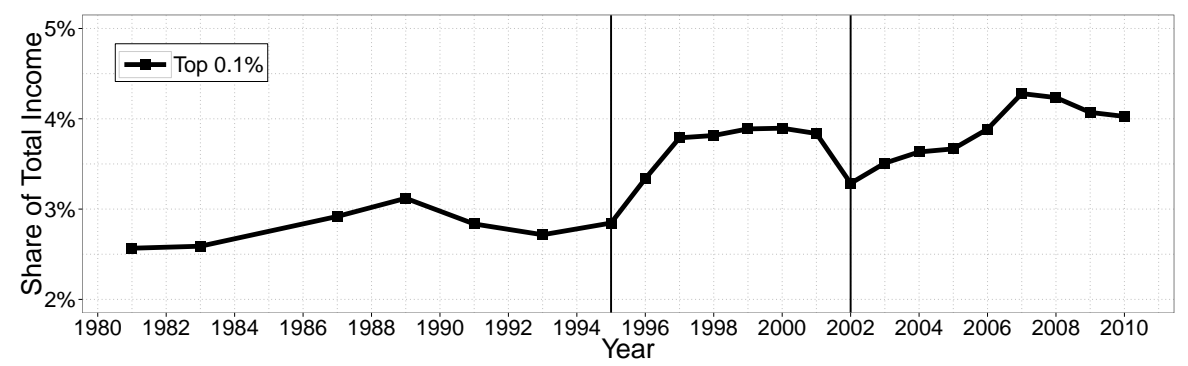

(a) Top $0.1 \%$ income shares

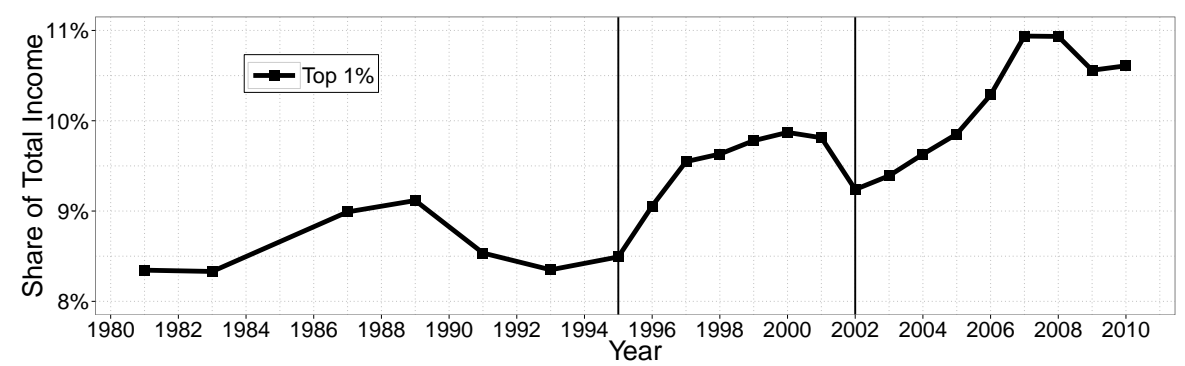

(b) Top $1 \%$ income shares

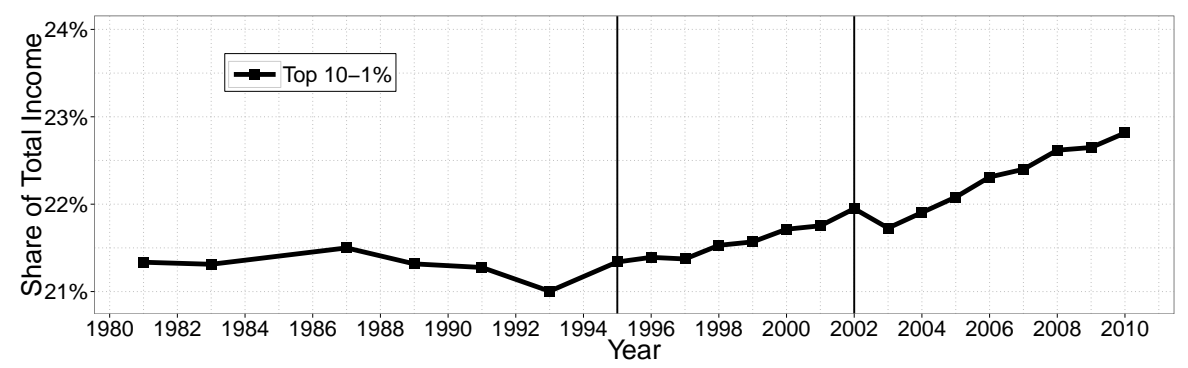

(c) Top 10-1\% income shares

Figure 2: Swiss top income shares, 1981-2010

Note: Top income shares for different top groups. The two vertical lines demarcate the period 1995-2002, for which top shares have been imputed using the synthetic control method. Source: Federal income tax statistics, own calculations.

the 1980 s to 2010 , and the previously missing years 1995 to 2002 are no exception. Yet there are differences between the top groups, with larger increases further up in the income distribution. ${ }^{14}$ While the top $10 \%$ group experienced an increase of $13 \%$ over the whole period, the increase for the top $1 \%$ was $27 \%$ and added up to $100 \%$ for the richest 450 tax units belonging to the top $0.01 \%$ (see Table 2). These cumulative growth rates were even larger in 2008 for most of the top groups, the year right before the out break of the global Financial Crisis. Panel c) in Figure 2 also suggests that it is the higher percentiles in the income distribution that tend to have more volatile earnings, which is

\footnotetext{
${ }^{14}$ The finding that the top decile is a heterogeneous income group has been pointed out in previous research by Atkinson and Piketty (2007, 2010 and Roine et al. (2009).
} 
confirmed by the variance of periodical growth rates reported in Table 2 .

Table 2: Growth in income shares of top groups, 1981-2010

\begin{tabular}{lcccccc}
\hline & Top 10\% & Top 10-1\% & Top 1\% & Top 0.5\% & Top 0.1\% & Top 0.01\% \\
\cline { 2 - 7 } Growth & $12.61 \%$ & $6.93 \%$ & $27.12 \%$ & $34.35 \%$ & $56.86 \%$ & $100.08 \%$ \\
Variance & 1.745 & 0.528 & 13.998 & 21.725 & 56.006 & 131.343 \\
Growth p.a. & $0.42 \%$ & $0.23 \%$ & $0.90 \%$ & $1.14 \%$ & $1.90 \%$ & $3.34 \%$ \\
Max growth & $13.04 \%$ & $6.93 \%$ & $31.07 \%$ & $39.93 \%$ & $66.73 \%$ & $116.31 \%$ \\
in year & 2008 & 2010 & 2008 & 2008 & 2007 & 2008 \\
\hline \hline
\end{tabular}

Note: Total and average annual growth in income shares of different top groups, 1981-2010.

Swiss top income shares are strongly correlated with the business cycle. The last recession covered in the data is the so-called "dot-com bubble" in 2001. After a peak in 2000, we observe a drop in income shares for all top groups. The dynamics are slightly different between the very top and the top decile as a whole. For the latter group, income shares fell in 2001 and 2002, but then also recovered quickly: in 2005 they had reached pre-recession levels and continued to rise (see Figure 3.a). Further at the top, the drop was steeper yet the recovery still happened almost as quick as for the top decile as a whole. However, despite these differences, by the end of the time span covered, all groups have attained shares in total income above any level reached before.

Research on top incomes suggests that these have become more cyclical since the 1980s (Saez, 2013). Using a panel of 16 countries, Roine et al. (2009) find that growth benefits the top $1 \%$ group the most, while Guvenen et al. (2012), who use a large panel of individuals in the U.S. for 1978-2011, find that those belonging to the top $1 \%$ and $0.1 \%$ experience the largest income drop when entering a recession. In fact, their drop in income is larger than for those in the 90th percentile. Guvenen et al. (2014) further find that the top $1 \%$ in the U.S. have more volatile income than the rest of the population, but that this difference cannot be explained by business fluctuations alone. They find that the volatility varies by industry: the finance, insurance and real estate industry is the most cyclical for the top $1 \%$ earners.

This picture is in line with income distribution theories, which attribute a higher 
volatility to more disperse distributions, especially at the top (see Neal and Rosen, 2000, for an overview). Another possible explanation for the observed higher volatility at the very top lies in the relative importance of capital income combined with the different composition of wealth at the very top compared to the top groups in the lower percentiles: the share of wealth held in corporate stock increases at the very top of the wealth distribution, while the share of other assets generating more stable returns, especially real estate, decreases with wealth as evidence from the U.S. shows (Kopczuk and Saez, 2004; Saez, 2006).

\section{Long Run Development}

As the series presented in this study are constructed following the approach of Dell et al. (2007), we can combine our results with the latter to obtain top income shares series from 1933 to 2010. As shown in Figure 3, top income shares have remained remarkably stable over this period. This is especially true for the two decades from the mid-1970s to the mid-1990s. Thereafter we observe a steady increase which made some top groups, such as the top $10 \%$, reach, by the end of the last decade, the highest share in total incomes they had ever experienced.

The long term picture also provides further evidence for a steeper increase at the very top of the income distribution. Panel c) of Figure 3 shows how the top $0.1 \%$ outperformed neighboring groups, especially so in the last decade for which data is available. Figure 4 makes this point even more clearly by comparing the top $10 \%$ within the top $10 \%$ (i.e., the top $1 \%$ of the entire population as a share of the top $10 \%$ group) and within the top $1 \%$ group, respectively. While these within-group shares were more or less equal from 1933 to the beginning of the 1970 s, the top $10 \%$ within the top $1 \%$ started to rise and drift away thereafter. Similarly, the ratio of the average income of the tax units of each top group relative to the total average income has been steadily increasing ever since the mid-1990s, after having reached its trough in the 1970s and 1980s. For the top $0.01 \%$ of tax units, i.e., the 450 richest households in Switzerland, average earnings have climbed up to 180 times the average earnings in the economy - an unprecedented level.

\section{International Comparison}




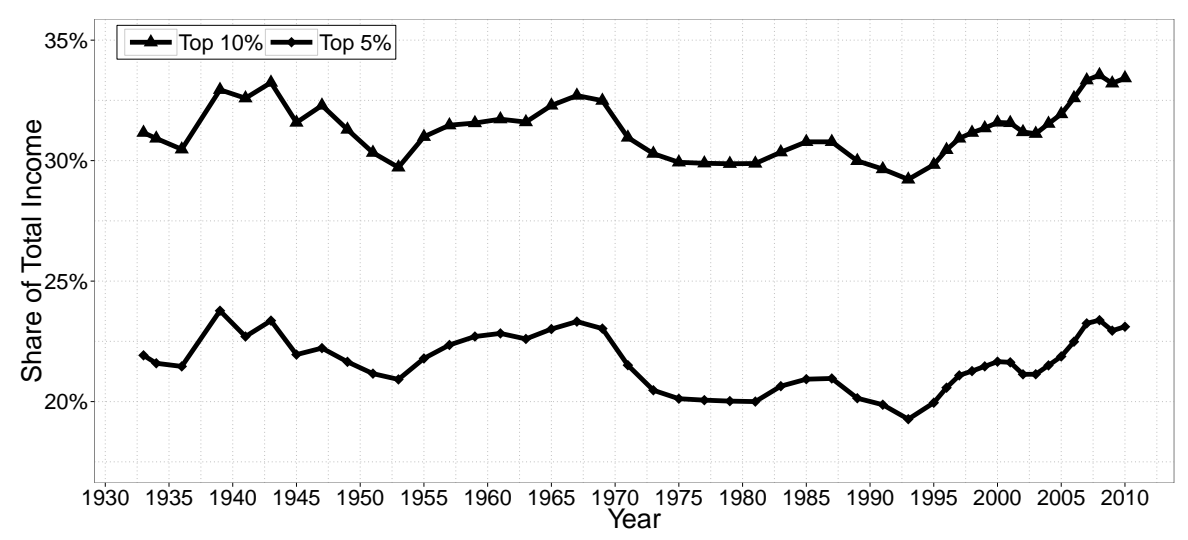

(a) Top $10 \%$ and top $5 \%$ groups

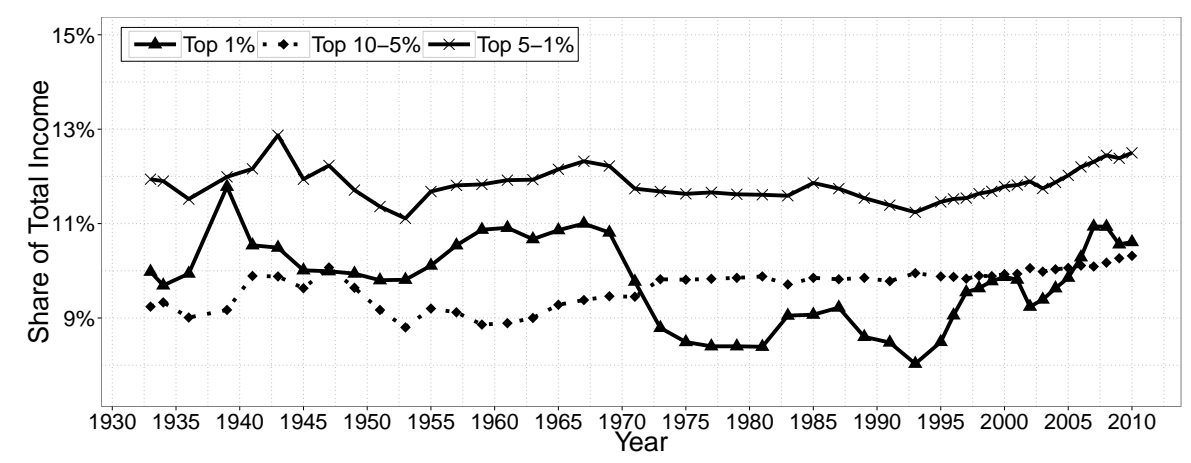

(b) Top $1 \%$, top $5-1 \%$, and top $10-5 \%$ groups

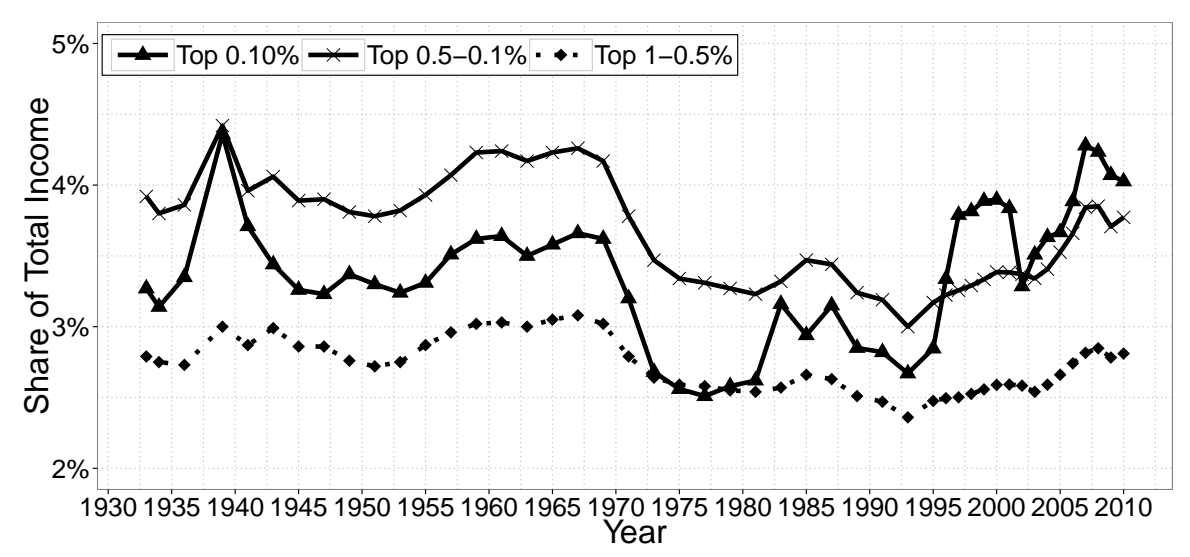

(c) Top $0.1 \%$, top $0.5-0.1 \%$, and top $1-0.5 \%$ groups

Figure 3: Long run evolution of top income shares in Switzerland, 1933-2010

Note: Top income shares for different top groups. Years 1995-2002 imputed using synthetic control. Source: Federal income tax statistics; 1933-1993: Dell et al. (2007), 1995-2010: own calculations.

In comparison to the experience of other countries, top $1 \%$ income shares in Switzerland have remained fairly stable since the 1930s, with a dip at the end of the 1960s. When in the 1980s top income shares in the U.S. started to shoot up, Switzerland underwent an experience similar to its neighbors Germany and France, which both experienced an extremely stable evolution in top income shares. This picture changes when looking at 


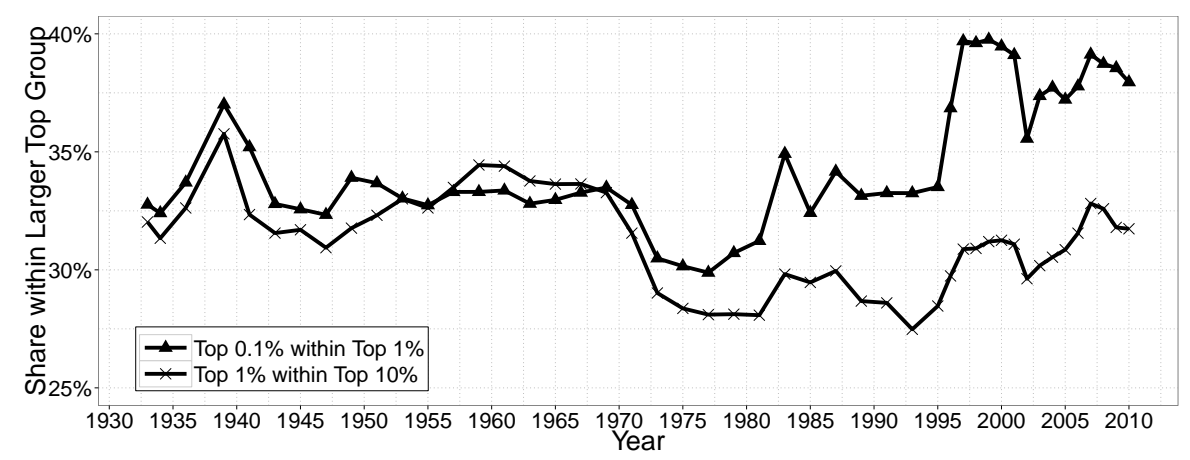

Figure 4: Shares within shares, 1933-2010

Note: Share of income going to the richest $10 \%$ within the top $10 \%$ and top $1 \%$, respectively. Source: Federal income tax statistics; 1933-1993: Dell et al. (2007), 1995-2010: own calculations.

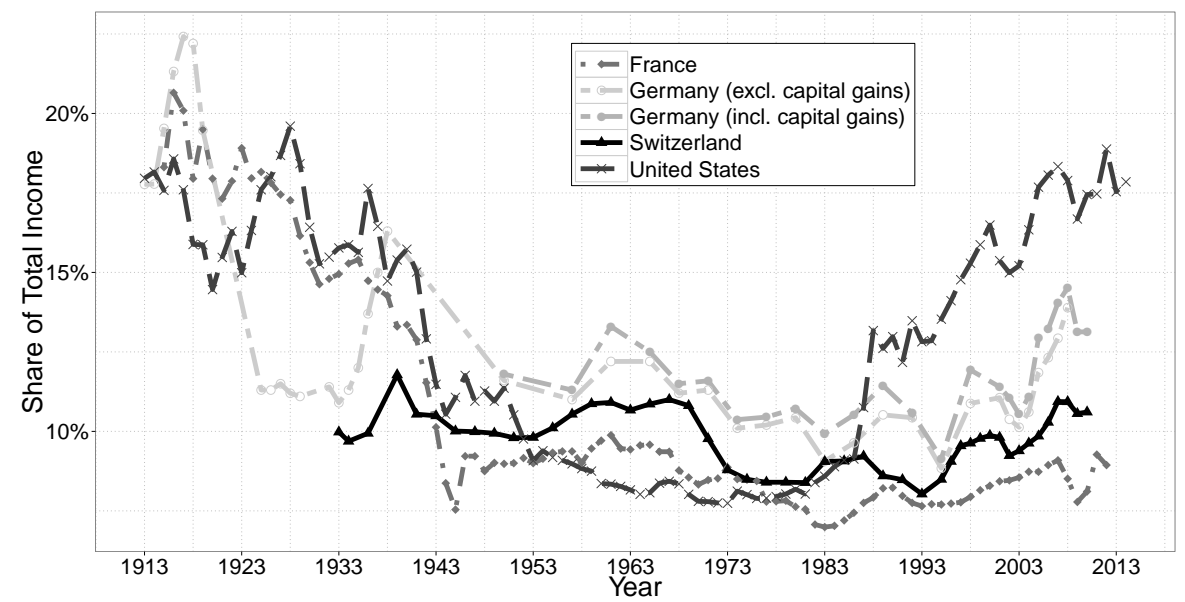

(a) Top $1 \%$ groups in four developed countries

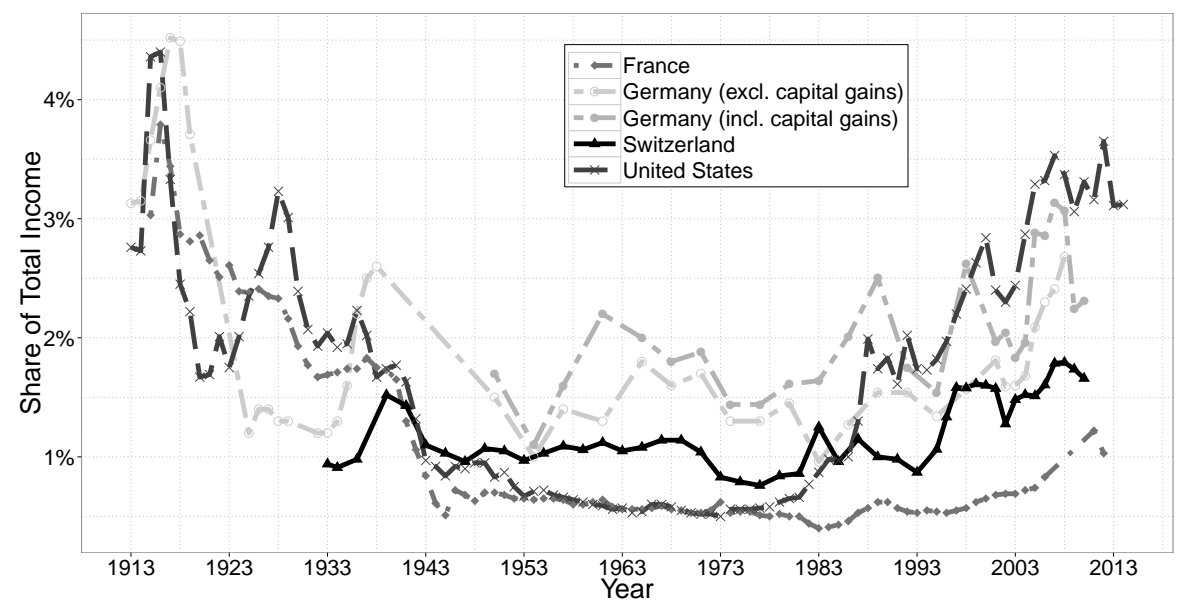

(b) Top $0.01 \%$ groups in four developed countries

Figure 5: Top income shares in international comparison, 1913-2013

Source: The World Wealth and Income Database, Alvaredo et al. (2016)

the top $0.01 \%$ groups depicted in Figure 5b. This group comes much closer to the U.S. experience with a pronounced increase starting in the 1990s and reaching unprecedented 
levels in 2007.

\subsection{Robustness Checks}

\subsubsection{Robustness of the Estimation Results}

\section{Prediction for Missing Years Using the Synthetic Control Method}

Figure 6 reports estimates from the synthetic control method together with the estimates from the OLS regressions and the imputed values. Estimates of the alternative methods (OLS and imputation) follow the same trend as our synthetic control estimates.

Besides the theoretical advantage (see Section 3.3 above) the synthetic control estimates perform better in the data for two reasons. First, the OLS as well as the linear imputation estimates lead to a strong increase in the top shares between 1998 and 1999, while the labor income shares (see below) stay flat during this period. Instead, the synthetic control captures this feature very well. Second, the synthetic control method leads to the smoothest evolution among the three methods. Given a generally increasing trend in top income shares, these estimates provide a conservative measure of inequality and income volatility at the top.

With respect to the observed evolution in recent years, the synthetic control estimates would have predicted a steeper increase for the top $10 \%$ and $5 \%$ groups and a lower increase for the top $0.1 \%$ and top $0.01 \%$ groups than what we observe in reality. This is in line with the hypothesis that there are underlying different trends in income inequality at the top and that the very top groups have experienced an extraordinarily large increase in their total income shares.

\section{OLS Estimates for the Missing Years}

The OLS estimates indicate that the increase in top income shares in the late 1990s could have been slightly larger and more pronounced. The peak emerging in 2000 is not observed in the synthetic control estimates, even though we observe such a peak in many (but not all) of the cantonal series. Again, we take this as indication that the synthetic control estimates are conservative in the sense that they do not overestimate the increase in inequality in the end of the 1990s. 


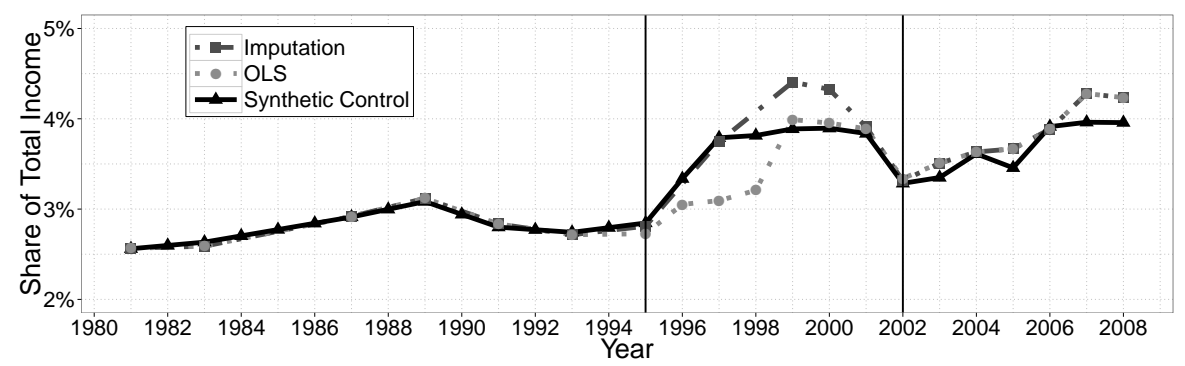

(a) Top $0.1 \%$ income shares

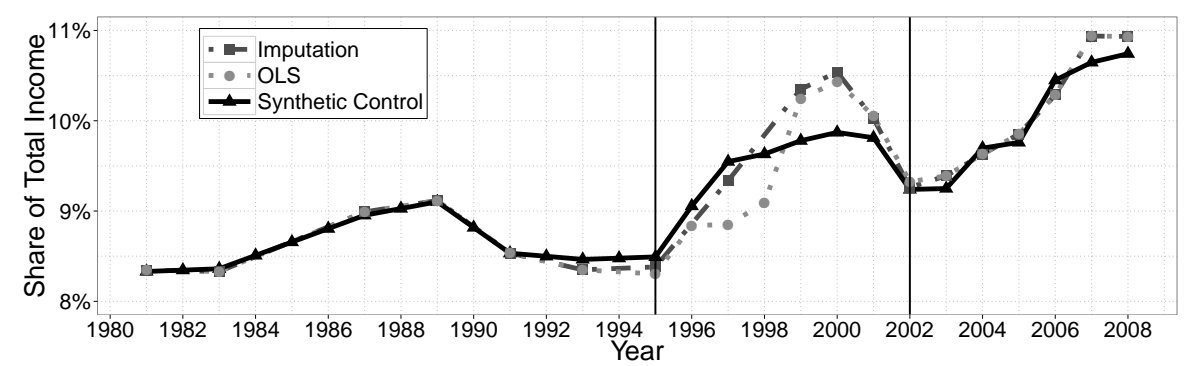

(b) Top $1 \%$ income shares

Figure 6: Comparison of different imputation methods for the years 1995-2002

Note: The series show the result of different imputation methods to estimate top income shares for the period 1995-2002 (demarcated by vertical lines), for which no federal income tax statistics are available. See text for details. Source: Federal income tax statistics, own calculations.

Detailed results of the OLS fixed-effects regressions used to predict the missing years can be found in Table 7 in the Online Appendix. The overall fit of the different models for all the different series of top income shares is good and the share of explained variation is very high. Model I with Basel-Stadt (BS) as the only regressor achieves the lowest $R^{2}$, but even there the values range between 0.84 for the top $10 \%$ group estimates and 0.90 for the top $0.1 \%$ group. In models II and III the coefficient for Basel-Stadt turns out to be insignificant except for the top $0.01 \%$ shares. The coefficients in models II and III are robust to the exclusion of BS. This makes sense considering Basel's small size and therefore little impact on the overall distribution of incomes. At the same time some of the richest entrepreneur families in Switzerland come from BS, the canton with the highest Gini coefficient in wealth distribution (0.91 in 2008, see Peters, 2011), as well as an above-average Gini coefficient in tax incomes (Jeitziner and Peters, 2009).

\section{Predicting Missing Years by Imputation}

While the imputed values in Figure 6 follow a pattern very similar to the OLS estimates for the groups from the top $10 \%$ group to the top $1 \%$ group, the estimates further towards 
the top become very large and volatile. Especially for the top $0.1 \%$ and top $0.01 \%$ groups, the estimated values around the year 1999 become even larger than the estimates in 2008. Such an overshoot of top income shares, followed by a large decline just within a few years, does not seem plausible. So while imputation gives reasonable estimates for the top shares, this technique is not precise enough to impute values at the very top, as these series are more volatile than the ones for the lower top groups.

\section{Accuracy of the Pareto Distribution Assumption}

To check for the accuracy of the Pareto interpolation method, we make use of the old age insurance data $(A H V$-Statistik). For these labor incomes, we obtained the exact percentiles upon request (for details, see Section 5) together with tabulations with the same brackets as those reported in the tax statistics. This allows us to Pareto interpolate the AHV data in the same way as we did with the tax statistics. The resulting estimates of the top shares turn out to be very precise, with deviations between 0 and 0.5 percentage points. Similarly, the deviations of the estimated income thresholds from the true values range between a few Swiss Francs up to a couple of thousand Francs. ${ }^{15}$ So even though grouped income data seem to be merely a relatively rough measure of the true income distribution, the Pareto interpolation method ensures highly precise results even for very small percentiles such as the top $0.5 \%$ group. Even more, the top $0.1 \%$ and $0.01 \%$ shares, which have been extrapolated whenever not contained in the top bracket, are as precise as the interpolated values. ${ }^{16}$

\section{Pareto Interpolation Results in Comparison to Dell et al. (2007)}

When comparing the results for 1981/82-1992/94 to those of Dell et al. (2007), the estimates are very similar although not exactly identical. This has different reasons. First, our estimates of the total tax units in the country are based on yearly register data and not on linear interpolation between decennial censuses. Second, we also use a total in tax units that is slightly smaller than the one in Dell et al. (2007) (see Appendix C for details). Note, however, that differences in the denominator do not matter very much as

\footnotetext{
${ }^{15}$ For the group of self-employed, for some single years, the deviations jump to CHF 100,000. We attribute these changes mainly to measurement errors in the data.

${ }^{16}$ This is the case for employees in the years after 2000 and for the self-employed over the whole period.
} 
the top shares calculated upon the total reported tax income instead of the denominator that corrects for non-filers do not change much. Without the correction for total income, the income shares of the top $10 \%$ are overestimated by less than 2 percentage points and those of the top $0.01 \%$ by 0.07 percentage points, compared to the estimates where the correction for total incomes has been made. Overall, the differences between the estimates presented in our study and those reported by Dell et al. (2007) are very small, ranging between 0.006 and 0.347 percentage points or $0.6 \%$ and $7.4 \%$. This is still in an acceptable range, for as Atkinson et al. (2010) put it in their meta study, "there is a wide confidence interval surrounding the estimates, reflecting not sampling error [...] but non-sampling error" (p.678). They suggest an error margin of $\pm 20 \%$.

\subsubsection{Is it a Data Phenomenon? System Change and Tax Evasion}

\section{Change from Biennial to Annual System}

The change from the biennial to the annual assessment of incomes has only minor quantitative effects. There is no visible jump in the top shares, and even though they started to rise after 1993, the rise was slow in the beginning and can be seen as the beginning of an era of increasing top income shares which became especially pronounced from the end of the 1990s onward. Using individual federal income tax data for the canton of Zurich ${ }^{17}$ we simulate the effect of averaging incomes over two years on the estimated top income shares for the period 2001-2010. The effect is of minor size, ${ }^{18}$ suggesting that true inequality was only slightly higher in the pre-reform period than what we measure with the tax statistics. The absence of a sudden rise is likely due to the fact that betwixt assessments had been increasing prior to the reform, gradually leading to more annual assessments already under the biennial tax regime.

\section{Changes in Tax Evasion}

A potential concern is that the observed increase in top income shares is driven by a

\footnotetext{
${ }^{17}$ Source: Federal Tax Administration ESTV, Bern; access through SNF Sinergia grant 130648 "The Swiss Confederation: A Natural Laboratory for Research on Fiscal and Political Decentralization".

${ }^{18}$ Compared to an annual system, averaging the incomes over two years reduces the estimated top $10 \%$ income share by 0.5 percentage points on average, and the top $1 \%$ by 0.3 percentage points, respectively. See Table 1 in the Online Appendix.
} 
decrease in tax evasion. This could be due to the prevalence of electronic payment systems or because top tax rates in Switzerland have been decreasing, thereby reducing the incentives to evade taxes. Several aspects speak against this conjecture. First, the fraction of non-filers was increasing over the period of our study. This is consistent with the findings in Feld and Frey (2006), according to which tax evasion varies between $12.6 \%$ in 1978 and $35.1 \%$ in 1990 . Second, speaking to officials from different cantonal tax administrations confirmed our view that tax evasion has not decreased over time, some officials from the administration even suspecting an increase in tax evasion. Third, while in some cantons the change to the postnumerando taxation was accompanied by the introduction of new IT systems allowing a better cross-checking of tax return data, the drawback of the yearly assessment seems to be that tax collectors have less time to investigate suspicious cases. Yet all the officials we spoke to agreed that income tax evasion is an offense mostly committed by low- and middle-income households. They argued that for top earners the issue is more the evasion of wealth taxes and casual income (earned abroad). Overall, it is not plausible that the observed increase in top income shares is due to more compliance.

\subsubsection{High Income Foreign Residents and Other Special Cases in the Data}

Switzerland is well-known to be an attractive country for high-income residents. The so-called special cases in the Swiss tax statistics, which are included in our estimates, are therefore of particular interest. There are two important groups: (i) expenditurebased taxpayers, i.e. the "tax deals", and (ii) tax units with taxable income below ratedetermining income. The latter case emerges when taxpayers have incomes already taxed abroad (e.g., foreign real estate), or tax units not subject to taxation in Switzerland for a full fiscal year (e.g., tax units who emigrate). Information on taxpayers generating income in several countries is a particular feature of the Swiss tax data. ${ }^{19}$ Expenditurebased taxation is available to foreign taxpayers who relocate to Switzerland, under the condition that they do not work in Switzerland. Swiss citizens can opt for this special

\footnotetext{
${ }^{19}$ This differentiation cannot occur in the U.S., for instance, because for U.S. citizens and residents their global income is taxed in the U.S.
} 
treatment in their first year of residing in the country after an absence of at least ten years and again under the condition of not pursuing any kind of work in Switzerland.

Expenditure-based taxpayers are taxed according to their own and their Swiss-based dependents' living expenditures, rather than according to their income. The sum of these expenditures has to equal at least five times the (imputed) rent (in case of homeowners). For taxpayers living in hotels, pensions, or homes for the elderly the tax base has to equal at least twice their expenditures for room and board. In addition, a control calculation makes sure that the tax is not lower than the regular tax on Swiss income sources would be, namely real estate incomes and all kind of capital incomes, patents, and pensions from Swiss sources. Incomes from abroad are taken into account if the taxpayer claims an exemption from the foreign income tax.

Contrary to common wisdom, expenditure-based taxpayers do not get a special tax deal in the sense that they negotiate over a different tax rate. Their tax base is simply calculated upon their expenditures rather than upon their income. ${ }^{20}$ This sum of expenditures is then taken as base to calculate the tax as if it were taxable income. If applicable, a tax payer proposes expenditure-based taxation not only because she wants to decrease the tax burden, but also to reduce the costs associated with tax filing. If income streams are a complex mix of different sources from different countries, opting for an expenditure-based tax deal may be less costly, and it guards the taxpayer from becoming under suspicion of tax fraud in other countries, since they legally pay their full taxes in Switzerland (Weibel, 2014). Therefore, it is not a priori clear whether this tax base, which enters our top income share estimates as income, is larger, smaller or much smaller than actual income would be. Although we expect these taxpayers' income to be larger than their reported tax base on average, there is at least some anecdotal evidence that expenditure-based taxpayers sometimes pay more taxes than they would on a regular basis. When the canton of Zurich abolished the expenditure-based taxation in 2010, about half of the 201 expenditure-based taxpayers left the canton, and among those who stayed, only 47 (i.e., approximately 50\%) paid higher taxes (Finanzdirektion

\footnotetext{
${ }^{20}$ It is still necessary to obtain an individual deal, called tax ruling, with the local tax administration who considers each case on an individual basis. This may explain the confusion.
} 
Kanton Zürich, 2012).

The second special group are those taxpayers where the rate-determining income does not equal taxable income, mostly because they earn income abroad which must be taken into account to calculate the tax rate. In these cases the Swiss tax rate is calculated upon the whole income, but is only applied to the income taxable in Switzerland. Again we cannot know by how much the statistics underestimate true income, but it is possible to report these cases.

Figure 7 shows exemplarily the importance of expenditure-based and special tax units among the top $0.1 \%$ group. In quantitative terms, special cases with global ratedetermining income higher than their income taxed in Switzerland are much more relevant within the top income groups than wealthy foreigners taxed according to their expenditures, and their share has been increasing since the 1970s. Not surprisingly, the share of special cases increases towards the top of the income distribution. This fact entails two interesting findings. First, top income earners in Switzerland are more prone to have incomes from abroad than the average taxpayer, a finding that becomes more accentuated towards the very top of the income distribution. Furthermore, the share of individuals earning income abroad has increased substantially over time, notably among very top groups. While in the 1970 s around $12 \%$ of the top $0.1 \%$ income earners were "special cases", by 2010 this share has increased to $34 \%$. In our view, this goes hand-in-hand with the observation that while Switzerland has a relatively equal wage distribution, inequality at the top resembles more the Anglo-Saxon countries. The very top income earners are truly "global": they seem to be able to take advantage of globalization more than the average, and their income process follows the corresponding worldwide trends for top incomes. Second, the presence of tax deals does not play a central role for a possible downward bias of top income shares. Very rich persons with income sources from abroad seem to find attractive tax conditions in Switzerland even without a special tax deal. For our overall results these findings indicate that our estimates on the evolution of top income shares should be taken as a lower bound and that the bias arising from special cases with several international income sources becomes larger for groups at the very top. 


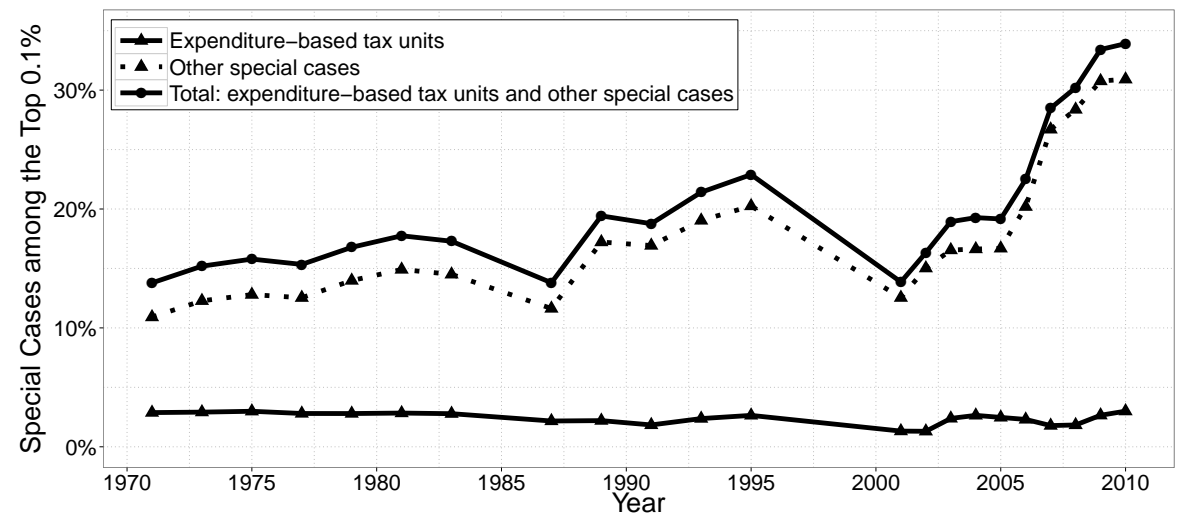

Figure 7: Expenditure-based tax units and special cases among the top $0.1 \%$

Note: Share of expenditure-based tax units and so-called special cases of taxpayers with rate-determining income different to taxable income among the top $0.1 \%$ group. Series for other groups can be found in Table 6 in the Online Appendix. Source: Individual federal income tax data, ESTV Bern, own calculations.

\section{Driving Factors of Top Income Shares: Labor vs.}

\section{Capital Incomes and the Distribution of Wealth}

The picture of top income shares we have obtained so far is based on total income. To better understand the driving factors behind the observed patterns, the next step would be to decompose total income into labor and capital income. The Swiss tax data do not allow such a distinction, but other sources do allow a closer look at the evolution of labor and capital incomes separately. For the former, we make use of the old age insurance statistics (AHV-Statistik), while for the latter we have to rely on estimates from wealth statistics. There is only limited cantonal information on how labor and capital income are correlated, so the discussion below is an educated conjecture of how the income composition within top groups has changed over time.

\subsection{The Increasing Importance of Labor Incomes}

The AHV statistics contain the full earnings information for all employees and selfemployed on a yearly basis. Moreover, as contributions to the old age insurance are not capped but are levied upon total labor income (including all wage components, such as equity pay), all labor incomes legally earned in Switzerland are covered. As the AHV 
statistics are a full sample, it is possible to obtain the percentile values of interest directly from the data. ${ }^{21}$ The obtained top income shares therefore correspond to the true shares within the labor income distribution (as opposed to total income in the case of the top shares estimated with tax statistics). An important difference between social security and tax statistics is that the former relies on individuals whereas the latter is based on tax units. To the extent to which the correlation between top incomes and household structure did not change, the evolution of top labor incomes may be directly compared to the evolution of total incomes. Hence, if top labor incomes grew faster than total incomes, labor incomes would have become relatively more important among the very top income earners.

Figure 8 shows the top labor income shares together with total top income shares from the income tax data. They clearly follow the same patterns, with the latter being higher for every top group at every point in time. Labor income is therefore more equally distributed than total income.

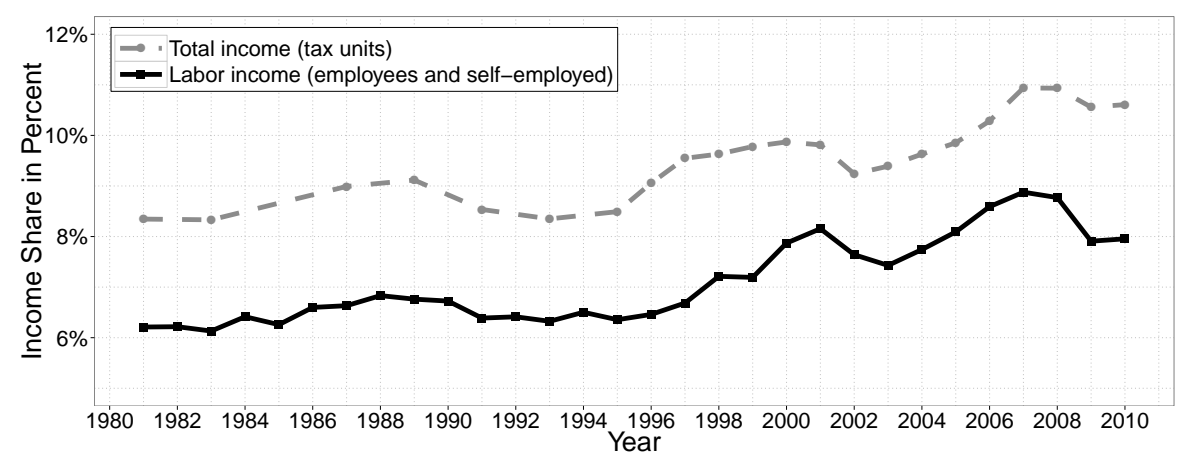

Figure 8: Top 1\% income shares of total income and labor income

Note: Income shares of the top $1 \%$ within the total income distribution (based on tax data), and the top $1 \%$ within the labor income distribution (based on social security data). Source: Total income: federal income tax statistics, labor income: AHV-Statistik; own calculations.

The AHV statistics further allow us to decompose labor income into wages paid to employees and income of the self-employed (Figure 9). Not surprisingly, the selfemployed at the very top have particularly high shares of the total income generated by all self-employed, also because some businesses generate only very low profits. ${ }^{22}$ For both

\footnotetext{
${ }^{21}$ We owe thanks to the data team of the Zentrale Ausgleichsstelle der $A H V$ (ZAS), especially to Hans-Peter Naef, who extracted the data we needed.

${ }^{22}$ Note that in the old age insurance statistics, the main income source determines whether someone is
} 
categories we observe again an upward trend starting in the mid-1990s, as well as an inverse 'U' pattern between 1999 and 2003, reflecting the boom and recession related to the "dot com" bubble in 2001. Similar to what we observe in the tax data covering all incomes, these patterns become more pronounced further up in the income distribution. This is even more so in the case of the self-employed, who experience stronger fluctuations as their incomes depend more on common economic trends than employees' incomes.

\subsubsection{The Rise of Top Employees}

The top self-employed and employees' incomes have grown differently since 1981, as depicted in Figure 10. While for the top $10 \%$ and (to a lesser extent) the top $5 \%$ it is true that entrepreneurs performed best when it came to securing large income shares, the increase in top employees' income shares is stunning. For the top $0.01 \%$ it more than tripled over the observed period, compared to the top self-employeds' shares, which less than doubled. These changes over time are of course limited, as the shares themselves are bounded above. Nevertheless Figure 10 clearly shows how the distribution of labor earnings in Switzerland has been undergoing some remarkable changes since the beginning of the millennium. While up to the mid-1990s the evolution of top incomes was similar for entrepreneurs and employees at the very top, employees benefited from a steady increase in their income shares. The top incomes of employees rose by more than $55 \%$, whereas total top income shares rose by only $30 \%$. Taken together this implies that while there has been a general increase in earnings inequality at the top as top income shares have been on a steady rise, this increase has been steeper for employees' incomes than for the self-employeds' incomes and total incomes measured by the tax data.

Further, we observe again that earnings at the top have become more volatile. This makes sense if we think of high self-employed earnings containing a risk premium, while for employees, wages can be seen as more predictable and stable. If now the increase at the top is partly due to more volatile salary components such as stock options and equity pay, top paid employees like CEOs will also bear part of the firm's risk. Note,

classified as an employee or as self-employed, therefore making sure that incomes from self-employment are their main labor income source. 


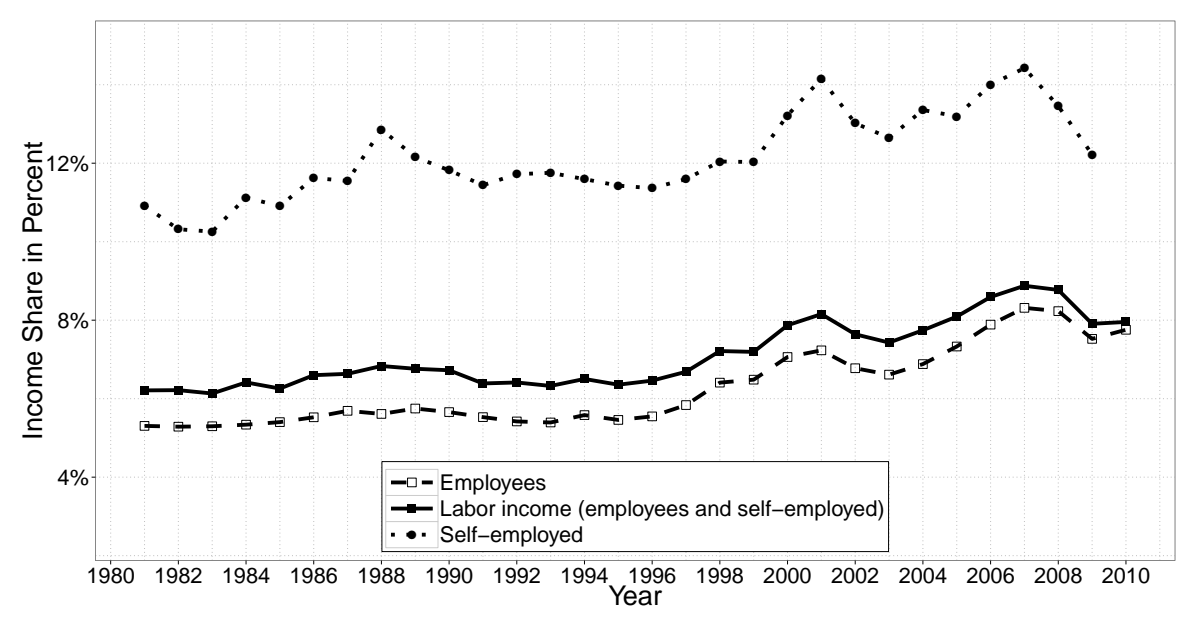

(a) Top 1\% income shares of employees and self-employed

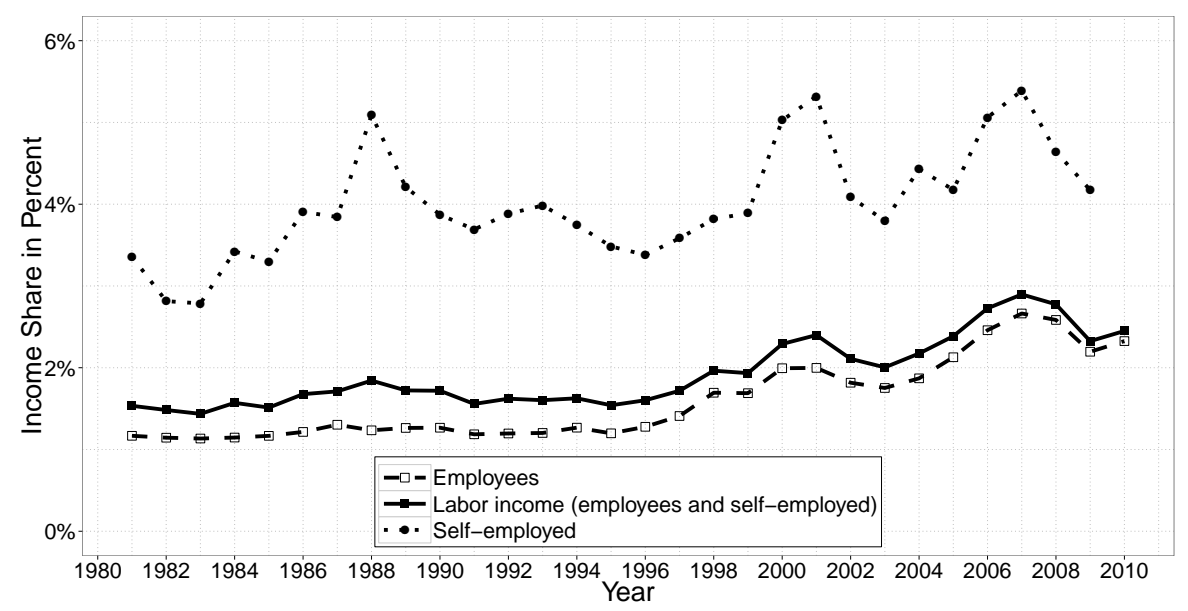

(b) Top $0.1 \%$ income shares of employees and self-employed

Figure 9: Top income shares of employees and self-employed, 1981-2010

Note: Labor income shares of the top $1 \%$ and top $0.1 \%$, respectively, of (i) all working individuals, (ii) employees, and (iii) self-employed. Self-employed not completely and finally assessed after 2008. The income denominator is (i) total labor income, (ii) total employee income, and (iii) total income of the self-employed, respectively. Source: AHV-Statistik, own calculations. 
however, that the upward trend still remains, as the declines are sharp but smaller than the increases. This pattern is consistent with the empirical literature, showing that CEOs are paid for luck but are not punished for bad outcomes (Bertrand and Mullainathan, 2001).

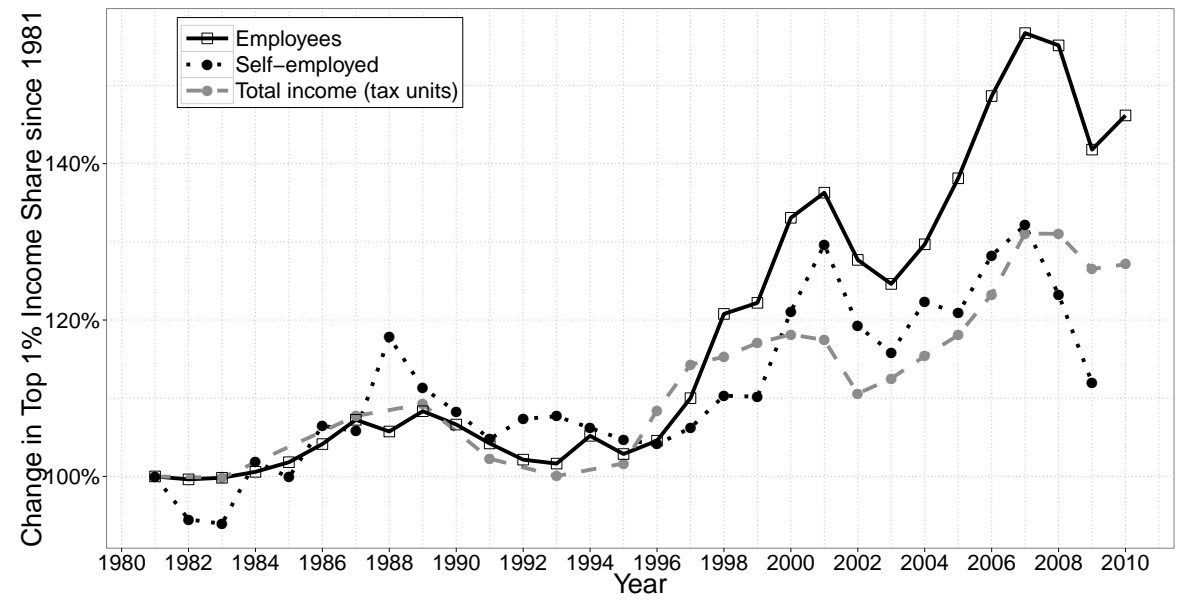

Figure 10: Change in top 1\% income shares of labor income of employees and selfemployed, and total income for all taxpayers, 1981-2010

Note: Change in income shares of different top groups, see Figures 9 a) and 2 b), own calculations.

The question is why we observe such a surge only after the mid 1990s. On the one hand, the literature has proposed market driven explanations such as skill-biased technological change which has favored top earners (see e.g. Gabaix and Landier, 2008). Some others have claimed that it is the institutional setting which matters and which has changed after the Reagan/Thatcher era, which was followed by a wave of liberalizations in many spheres (Pontusson, 2005). Related to this institutional view is a broad literature considering the effects of tax rates on top incomes. Piketty et al. (2014) present an overview of the different effects from taxation on top incomes along with a model including different margins of behavioral responses to taxation. The innovation of their model is that it includes top earners' responses of bargaining-over-pay, in addition to the standard supply-side and tax avoidance responses to taxation.

To gain more insights in the Swiss case we follow Gabaix and Landier (2008) and study the correlation between top labor incomes and the market capitalization of listed companies as a share of GDP. Figure 11 shows the striking result: the stock market capitalization of Swiss firms rose from around $70 \%$ of GDP to much over $250 \%$ of GDP 
in a short time period between the early 1990s and 2007. In an international comparison, these values clearly exceed those of other relatively small countries like the Netherlands and of larger countries such as France or Germany alike. Swiss stock market capitalization as a share of GDP is even higher than Luxembourg's in most of the years. The rise corresponds very well with the increase in top labor income shares (dotted line in Figure 11). The correlation between the two series is 0.745 and statistically significant at the $1 \%$ level.

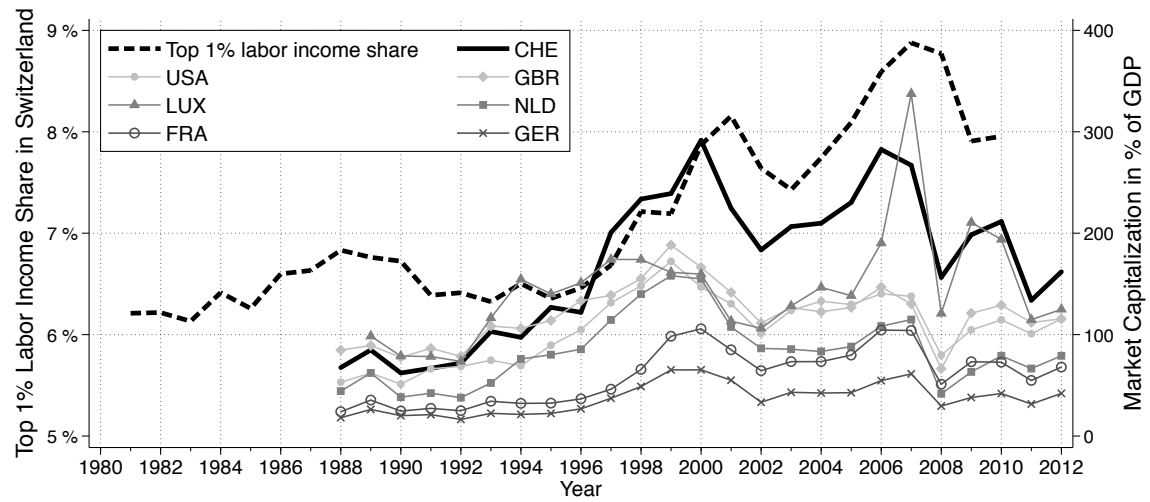

Figure 11: Top 1\% labor income shares and market capitalization in percent of GDP Note: Swiss top 1\% labor income share (left scale), and market capitalization of listed companies relative to GDP for different countries. Source: The World Bank, Development Index.

\subsection{Top Wealth Shares and Capital Incomes}

The second driver of top incomes are capital incomes. Our estimates of the evolution of capital incomes are much cruder than the estimates of labor income. To at least gain an idea of how the distribution of capital incomes has evolved, we look at the evolution of wealth inequality. Assuming that returns to capital do not vary systematically among the top groups, the evolution of wealth inequality is a good proxy for the evolution of capital income inequality. Figure 12 presents the top wealth shares from Dell et al. (2007), updated to 2011, estimated analogously to the top income shares. Wealth reported in the tax statistics is net (gross wealth minus liabilities) and relates to tax units (as in the case of incomes). Both panels of Figure 12 show that, as with top income shares, top wealth shares started to increase again in the 1990s, with the increase becoming more 
pronounced in recent years and further up in the income distribution. If we disregard the spike in the late 1930s, which is most probably caused by an influx of wealthy immigrants fleeing from the Nazis (Dell et al., 2007), wealth shares of the top 1\% group have risen to levels comparable to the post World War I period. Top $0.1 \%$ wealth shares have even risen so significantly since the early 2000s that they have reached unprecedented levels.

The numbers have to be interpreted with care, however, as pension accounts are tax free and therefore not included in the tax statistics. ${ }^{23}$ Individuals accumulate funded pension wealth through mandatory wage deductions through the employer ("2nd pillar"), and through optional individual contributions ("3rd pillar"). Annual contributions to both systems are capped. Their growth throughout the 20th century and in particular since their general introduction in 1984 leads to an overestimation of wealth concentration over time and in international comparison. While in 1969 the share of pension wealth in overall wealth amounted to 20\%, it has increased to $37 \%$ in 2011. To get a sense of how this affects top wealth share estimates, we compute two alternative wealth share estimates taking into account pension wealth. In both approaches, the total wealth denominator consists of taxable wealth plus all pension funds. ${ }^{24}$ In the first approach, each tax unit is assigned the average pension wealth, i.e, we assume that pension wealth is equally distributed, and the nominator is adjusted accordingly. This series therefore constitutes a lower bound for the wealth concentration. Our estimates, however, need not be too far off reality, since pension wealth is of lower importance for very wealthy individuals. This is confirmed by Bütler et al. (2016), who, based on SHARE (Survey of Health Ageing and Retirement in Europe) data, find no correlation between non-pension wealth and pension

\footnotetext{
${ }^{23} \mathrm{In}$ addition, the tax value of real estate is typically lower than market value. For the middle class, residential property constitutes a large part of their wealth. The Swiss National Bank (SNB) collects data on financial and real estate assets by households since 1998 (excluding commercial property owned by individuals). Comparing the SNB data series with the tax data shows no divergence between the two series. Changes in top wealth shares are therefore not driven by changes in the assessment of real estate. The practice differs between cantons, but real estate is valued at $70-100 \%$ of market value (Decision by the Swiss Federal Court BGE 128 I 240), and market value is re-estimated every 10 to 15 years. If we set the households' real estate value at $80 \%$ of market values calculated by the SNB, taxable wealth amounts to $85-90 \%$ of the wealth calculated by the SNB, after correcting for pension wealth, see below. Details see Table 2 in the Online Appendix.

${ }^{24}$ We use two data sources for pension wealth: Data before 1999 are taken from Leimgruber (2008), based on the Federal Pension Fund Statistics. Data since 1999 are based on the SNB, Swiss Financial Account, Table 14.
} 
wealth in Switzerland. We have three possible explanations for the low correlation finding. First, pension wealth can be cashed out at retirement (but also to buy a house or to start a business). Tax incentives make it more profitable for rich people to cash out their pension wealth. Hence, many wealthy individuals have only taxable non-pension wealth but no pension wealth left. Second, individuals with relatively low pension wealth may compensate by saving outside of the public pension system. Moreover, for high-income earners, pension contributions are capped above. Finally, individuals with high levels of wealth may decide to work less and therefore accumulate less pension wealth. In the second approach we add to the nominator of each top wealth group the share in total pension wealth the same top group has in total labor incomes. The top $10 \%$ of workers, for example, has on average a labor income share of $28 \%$, hence the top $10 \%$ of the net wealth distribution are assigned $28 \%$ of pension wealth in addition. Since we only have top labor income shares for the years 1981-2010, we use the average labor income share of each top income group during this period for all the years. Since labor income and pension wealth have conceivably a low correlation, this second approach provides a conservative, upper bound estimate for the wealth concentration including pension wealth.

The results are depicted in Figures 13 a) and b). The quantitative effect of including pension wealth is very large. Assigning each taxpayer average pension wealth (dotted lines), the wealth share of the top $10 \%$ drops from $74 \%$ to $47 \%$ and the top $1 \%$ share drops from $40 \%$ to $25 \%$ in 2011. As expected, assigning proportional rather than average pension wealth has the strongest impact on the top 10\%, increasing their wealth share by roughly 7 percentage points in 2011. For the wealthiest $0.1 \%$ in contrast, the difference between the two methods is negligible. These corrected levels in top wealth shares are much more comparable to the wealth concentration in other countries with similar income concentration. In France, for example, top wealth shares equal $62 \%$ and $23 \%$ for the top $10 \%$ and top 1\%, respectively (Piketty, 2014). Furthermore, our corrected series show a secular downward trend in the wealth distribution, quite similar to other industrialized countries.

Nevertheless we observe an increase in the top $1 \%$ and the top $0.1 \%$ since the mid- 


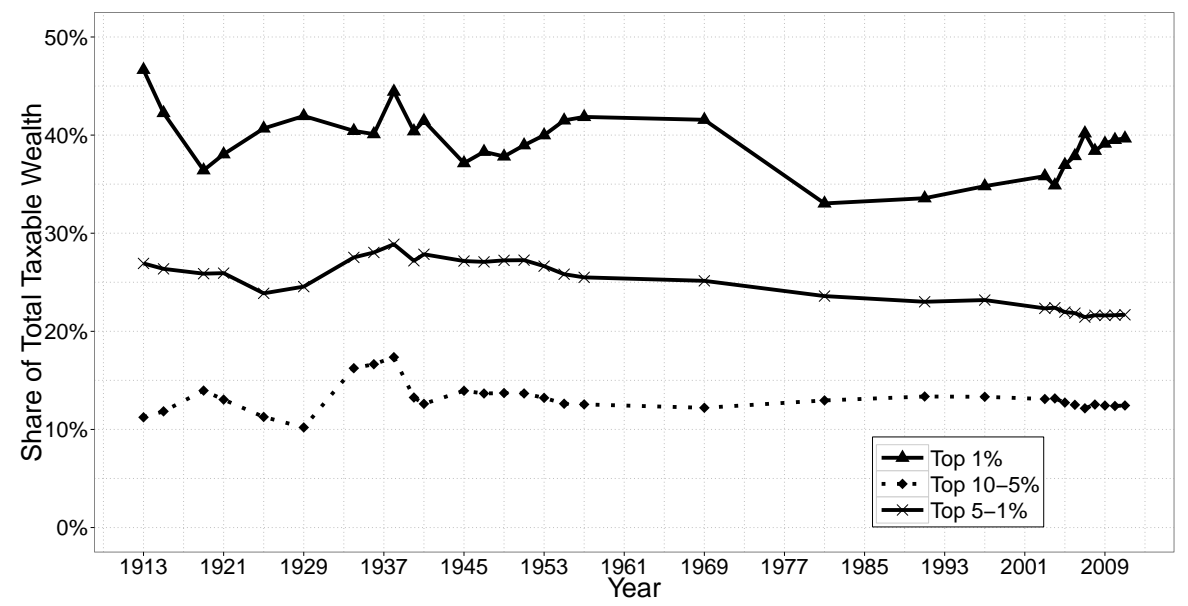

(a) Top $10-5 \%$, top $5-1 \%$, and top $1 \%$ groups

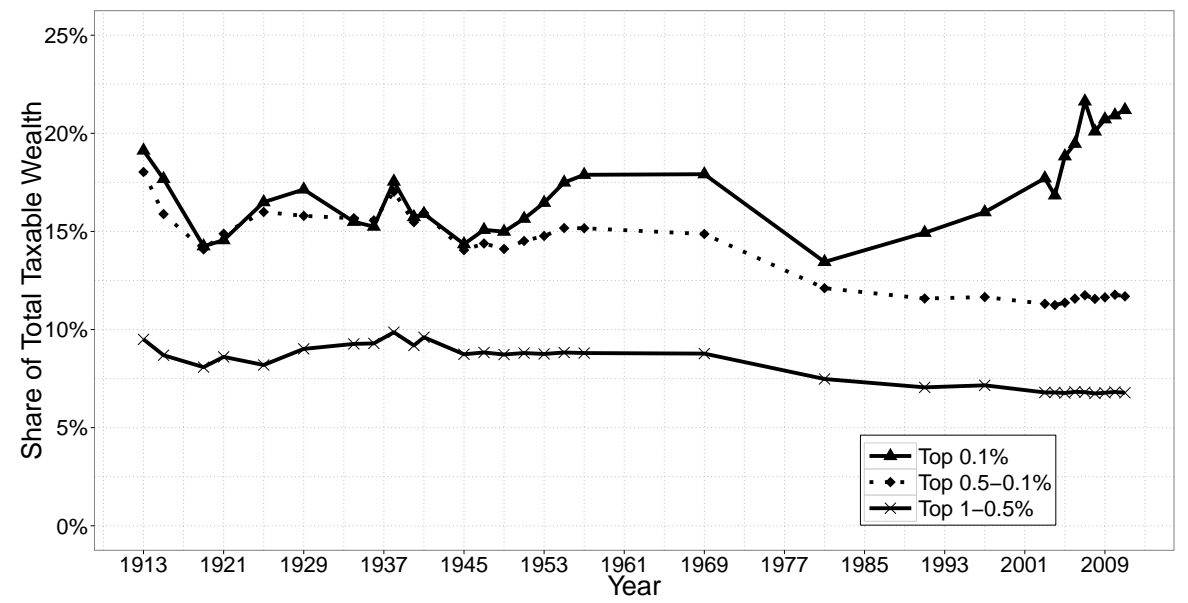

(b) Top $1-0.5 \%$, top $0.5-0.1 \%$, and top $0.1 \%$ groups

Figure 12: Top wealth shares in Switzerland, 1913-2011

Note: Shares in total wealth of different top wealth groups. Source: Wealth tax statistics, ESTV; years 1913-1997: Dell et al. (2007), 2003-2011: own calculations. 


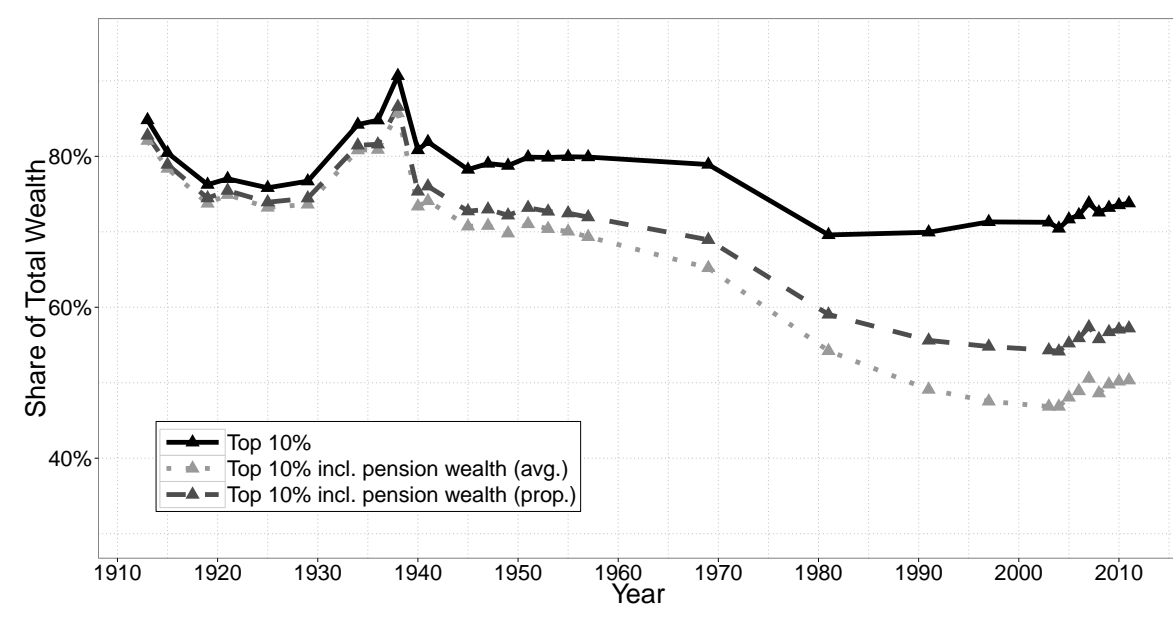

(a) Top $10 \%$ series

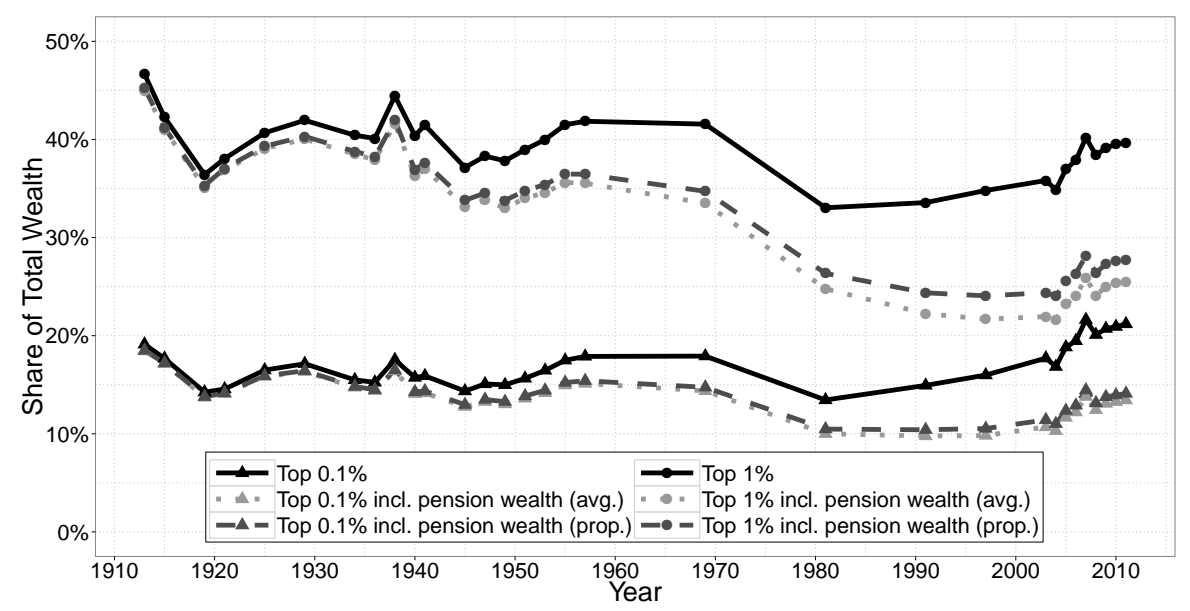

(b) Top $0.1 \%$ and top $1 \%$ series

Figure 13: Top wealth shares in Switzerland corrected for pension wealth, 1913-2011

Note: Series of (i) shares in total wealth of different top wealth groups, and (ii) shares in total wealth corrected for funded pension wealth. In 1930s coverage of wealth in tax statistics is particularly low, possibly leading to larger noise in the top wealth share estimates than in other periods. Source: Wealth tax statistics (ESTV), pension wealth statistics (1925-1996: Leimgruber, 2008, 2003-2011: SNB, Household Wealth Statistics), top wealth shares (1913-1997: Dell et al., 2007, 2003-2011: own calculations).

1990s in both the uncorrected and the corrected series. In fact, the rise in the top $10 \%$ wealth share is due to the increase of the top $0.1 \%$ alone. It is interesting to confront this fact with our finding that the share of globalized incomes among top income earners has risen. The SNB collects data for off-shore wealth held by Swiss (and foreign) residents since $1998 .^{25}$ Between 1998 and 2007, we see a strong co-movement of off-shore wealth

\footnotetext{
${ }^{25}$ The seminal contribution by Zucman (2013) analyzes off-shore wealth and he uses data on fiduciary wealth as well, available since 1976. These deposits are of minor importance for Swiss residents, however, since inter alia the Swiss anticipatory tax on dividends, which is withheld at source, still applies. The value of fiduciary deposits did not exceed $5 \%$ of other off-shore wealth held by Swiss residents in the period 1998-2014, for which the SNB data is available (see Table 3 in the Online Appendix).
} 
and top wealth shares. The value of off-shore portfolios at current prices almost doubled from 554 billion USD in 1998 to 1.083 trillion USD in 2007. The share of off-shore wealth in total wealth as measured by the SNB (see footnote 25) rose from $32 \%$ to $43 \%$ in that period. Looking at securities only, the share of foreign issuers shortly exceeded that of domestic issuers in the year 2007. After the financial crisis the value of foreign assets decreased and stabilized at around 1 trillion USD which amounts to $31 \%$ of total wealth. However, as noted by Zucman (2013), most of off-shore wealth is held by foreigners. Their off-shore wealth equaled $187 \%$ of the Swiss residents' counterpart in 1998, only to increase to $201 \%$ in 2007, and to decrease to levels around 175\% in 2014 (Source: SNB, see Online Appendix Table 3).

Interestingly, top wealth shares have decreased only a little since 2007, whereas offshore wealth was repatriated at large. To sum up, until 2007, the off-shore wealth increased in line with the top wealth shares, however, wealth shares seemed only little affected by the decrease of off-shore wealth, both by Swiss residents and foreigners, thereafter.

\section{Conclusion}

In this paper, we investigated the evolution of top income and top labor income shares in Switzerland. In particular, we have closed the data gap between 1993 and 2003 which arose because the cantons changed their tax systems at different points in this time frame.

Our results show that top income shares in Switzerland have increased, with stronger increases at the very top: the top $1 \%$ income share rose from $8.5 \%$ in the late 1980 s to $11 \%$ in the late $2000 \mathrm{~s}$, whereas the top $0.1 \%$ share increased from $2.9 \%$ to $4.2 \%$ in the same period. Together with the large increase, the very highest incomes also exhibited the largest volatility over the business cycle.

We also compared the income data from the tax statistics with the labor income data from the social security statistics, for which we obtained the percentiles directly from the register data. We find that inequality among the best paid workers (employees and self- 
employed) rose sharply as well, with the same time trend as the estimated values for total top incomes. The latter finding underpins our estimates of total income shares for the missing years 1995-2002. Furthermore, the share of top labor incomes has grown faster than total top incomes. In this respect, Switzerland follows the trends of other industrialized countries, where labor income has been found to have become more important among the top income groups (Atkinson et al., 2011).

The increase in top wealth shares has been more moderate than the increase in top income shares. Only the top $0.1 \%$ of the wealth distribution have substantially increased their share in total wealth, reaching unprecedented levels in the past decade. The concentration as well as the increase in top wealth shares, however, is reduced substantially once we correct for funded pension wealth.

Summing up we find that inequality among the very top resembles more the experience of Anglo-Saxon countries. This coincides with our finding that the very top income earners in Switzerland are truly "global": they seem to be able to take advantage of globalization more than the average, and their income process follows the corresponding worldwide trends for top incomes.

Further research is needed to investigate the hypothesis that falling top marginal tax rates could partially explain the rise of incomes at the very top of the distribution. Falling tax rates, especially in a country with strong direct democratic institutions, might be correlated with more fundamental changes in values. If, following the Reagan/Thatcher era, more free-market oriented values were adopted in politics and by the general public, this could also help explain trends in increasing pay at the top, combined with the emergence of incentive-based remuneration schemes. Such schemes can do both enhance efficiency and camouflage rent-seeking behavior. Using individual data it would be possible to investigate patterns of CEO compensation across industries over time in Switzerland. We leave these considerations for future research. 


\section{References}

Abadie, Alberto, Alexis Diamond, and Jens Hainmueller (2010) "Synthetic Control Methods for Comparative Case Studies: Estimating the Effect of California's Tobacco Control Program." Journal of the American Statistical Association, 105(490): 493-505.

Abadie, Alberto, Alexis Diamond, and Jens Hainmueller (2015) "Comparative Politics and the Synthetic Control Method." American Journal of Political Science, 59(2): $495-510$.

Abadie, Alberto, and Javier Gardeazabal (2003) "The Economic Costs of Conflict: A Case Study of the Basque Country." The American Economic Review, 93(1): 113-132.

Alvaredo, Facundo (2011) "A Note on the Relationship Between Top Income Shares and the Gini Coefficient." Economics Letters, 110(3): 274-277.

Alvaredo, Facundo, Anthony B. Atkinson, Thomas Piketty, Emmanuel Saez, and Gabriel Zucman (2016) "The World Wealth and Income Database." http://www.wid.world/.

Arnold, Barry C. (2008) "Pareto and Generalized Pareto Distributions." In Modeling Income Distributions and Lorenz Curves. ed. by Duangkamon Chotikapanich, 5 of Economic Studies in Equality, Social Exclusion and Well-Being, New York: SpringerVerlag, 119-145.

Atkinson, Anthony B., and Thomas Piketty (2007) Top Incomes over the Twentieth Century: A Contrast Between European and English-Speaking Countries. Oxford: Oxford University Press.

Atkinson, Anthony B., and Thomas Piketty (2010) Top Incomes: A Global Perspective. Oxford: Oxford University Press.

Atkinson, Anthony B., Thomas Piketty, and Emmanuel Saez (2010) "Top Incomes in the Long Run of History." In Top Incomes: A Global Perspective. eds. by Anthony B. Atkinson, and Thomas Piketty, Oxford: Oxford University Press, , Chap. 13 664-760.

Atkinson, Anthony B., Thomas Piketty, and Emmanuel Saez (2011) "Top Incomes in the Long Run of History." Journal of Economic Literature, 49(1): 3-71.

Bechtel, Michael, Dominik Hangartner, and Lukas Schmid (2016) "Compulsory Voting, Habit Formation, and Political Participation." mimeo, University of St. Gallen.

Bertrand, Marianne, and Sendhil Mullainathan (2001) "Are CEOs Rewarded for Luck? The Ones Without Principals Are." The Quarterly Journal of Economics, 116(3): 901932. 
Brewer, Mike, Alastair Muriel, David Phillips, and Luke Sibieta (2008) "Poverty and Inequality in the UK: 2008."

Burkhauser, Richard V., Shuaizhang Feng, Stephen P. Jenkins, and Jeff Larrimore (2012) "Recent Trends in Top Income Shares in the United States: Reconciling Estimates from March CPS and IRS Tax Return Data." The Review of Economics and Statistics, 94(2): $371-388$.

Bütler, Monika, Kim Peijnenburg, and Stefan Staubli (2016) "How Much Do MeansTested Benefits Reduce the Demand for Annuities?" Journal of Pension Economics and Finance, forthcoming.

Dell, Fabien (2007) "Top Incomes in Germany Throughout the Twentieth Century." In Top Incomes Over the Twentieth Century: A Contrast Between Continental European and English-Speaking Countries. eds. by Anthony B. Atkinson, and Thomas Piketty, Oxford: Oxford University Press, , Chap. 9 365-425.

Dell, Fabien, Thomas Piketty, and Emmanuel Saez (2007) "Income and Wealth Concentration in Switzerland over the Twentieth Century." In Top Incomes Over the Twentieth Century: A Contrast Between Continental European and English-Speaking Countries.. eds. by Anthony B. Atkinson, and Thomas Piketty, Oxford: Oxford University Press, , Chap. 11 472-500.

Diekmann, Andreas (2004) Empirische Sozialforschung. Reinbek: Rowohlt Verlag, , 6th edition.

Eidgenössiche Steuerverwaltung ESTV (2003) Zeitliche Bemessung der Steuern (Steuerperiode, Bemessungsperiode und Veranlagungsperiode). Bern: Eidgenössiche Steuerverwaltung ESTV, Informationsstelle für Steuerfragen.

Feld, Lars P., and Bruno S. Frey (2006) "Tax Evasion in Switzerland: The Roles of Deterrence and Tax Morale." CREMA Working Paper No. 2006-13.

Finanzdirektion Kanton Zürich (2012) "Einkommenssteuerbelastung jetzt spürbar über dem schweizerischen Mittel.” Press Release, March 162012.

Gabaix, Xavier (2009) "Power Laws in Economics and Finance." Annual Review of Economics, 1(1): 255-294.

Gabaix, Xavier, and Augustin Landier (2008) "Why Has CEO Pay Increased so Much?." The Quarterly Journal of Economics, 123(1): 49-100.

Guvenen, Fatih, Greg Kaplan, and Jae Song (2014) "How Risky Are Recessions for Top Earners?." American Economic Review: Papers and Proceedings, 104(3): 1-6. 
Guvenen, Fatih, Serdar Ozkan, and Jae Song (2012) "The Nature of Countercyclical Income Risk." NBER Working Paper No. 18035.

Jeitziner, Bruno, and Rudi Peters (2009) "Regionale Einkommens- und Vermögensverteilung in der Schweiz. Untersuchung der Steuerdaten 2003 und der Entwicklung seit 1995/96." Bern: Eidgenössische Steuerverwaltung ESTV, http://www.estv .admin.ch/bundessteuer/dokumentation/00882/00888/index.html?lang=de, Accessed on January 122014.

Kopczuk, Wojciech, and Emmanuel Saez (2004) "Top Wealth Shares in the United States, 1916-2000: Evidence from Estate Tax Returns." National Tax Journal, 57(2): 445-487.

Leimgruber, Matthieu (2008) Solidarity without the State?: Business and the Shaping of the Swiss Welfare State, 1890-2000. Cambridge: Cambridge University Press.

Neal, Derek, and Sherwin Rosen (2000) "Theories of the Distribution of Earnings." In Handbook of Income Distribution, Volume 1. eds. by Anthony B. Atkinson, and François Bourguignon, Amsterdam: Elsevier, , Chap. 7 379-427.

Peters, Rudi (2011) "La répartition régionale de la richesse en Suisse: Une analyse de la statistique 2008 de la fortune des personnes physiques." Bern: Eidgenössische Steuerverwaltung ESTV, http://www . estv .admin.ch/dokumentation/00075/ 00076/00717/index.html?lang=de Accessed on January 122014.

Piketty, Thomas (2001) Les hauts revenus en France au XXe siècle. Inégalités et redistributions 1901-1998. Paris: Bernard Grasset.

Piketty, Thomas (2014) Capital in the 21st Century. Cambridge, MA: Harvard University Press.

Piketty, Thomas, and Emmanuel Saez (2006) "The Evolution of Top Incomes: A Historical and International Perspective." American Economic Review: Papers and Proceedings, 96(2): 200-205.

Piketty, Thomas, Emmanuel Saez, and Stefanie Stantcheva (2014) "Optimal Taxation of Top Labor Incomes: A Tale of Three Elasticities." American Economic Journal: Economic Policy, 6(1): 230-271.

Pontusson, Jonas (2005) Inequality and Prosperity: Social Europe vs. Liberal America. Ithaca: Cornell University Press.

Roine, Jesper, Jonas Vlachos, and Daniel Waldenström (2009) "The long-run determinants of inequality: What can we learn from top income data?." Journal of Public Economics, 93(7-8): 974-988. 
Saez, Emmanuel (2006) "Income and Wealth Concentration in a Historical and International Perspective." In Public Policy and the Income Distribution. eds. by Alan J. Auerbach, David Card, and John M. Quigley, New York: Russel Sage Foundation, , Chap. 5 221-258.

Saez, Emmanuel (2013) "Striking it Richer: The Evolution of Top Incomes in the United States (Updated with 2011 Estimates)." University of California, http:// elsa.berkeley.edu/ saez/ Accessed January 122014.

Schaltegger, Christoph A., and Christoph Gorgas (2011) "The Evolution of Top Incomes in Switzerland." Swiss Journal of Economics and Statistics, 147(4): 479-519.

Victoria-Feser, Maria-Pia (2000) "Robust Methods for the Analysis of Income Distribution, Inequality and Poverty." International Statistical Review, 68(3): 277-293.

Weibel, Joel (2014) "Pauschalsteuer: Der Himmel auf Erden." Die Zeit(40): , September 252014.

Zucman, Gabriel (2013) "The Missing Wealth of Nations: Are Europe and the US net Debtors or net Creditors?" The Quarterly Journal of Economics, 128(3): 1321-1364.

\section{Appendix A Data Sources}

\section{Tax Statistics}

Data set with grouped tax data provided by Raphaël Parchet, Università della Svizzera italiana USI. ${ }^{26}$ Original source: Federal Tax Office. This data set contains variables for each of the cantons plus Switzerland for the tax periods 1983/84 up to 2010, except for period 1987/88 for which raw data is completely missing. The lower bounds of the income brackets for this dataset are 60,000 70,000 80,000 (up to year 2000) 90,000, 100,000, 120,000, 150,000, 200,000,300,000, 400,000, 500,000, one million, and two million $\mathrm{CHF}$, respectively. For each income bracket the total number of tax units (Normaland Sonderfälle) and their total income within each bracket are reported.

\footnotetext{
${ }^{26}$ Before Université de Lausanne
} 


\section{Old Age Insurance Statistics (AHV-Statistik)}

Data provided by Hans Peter Naef, Zentrale Ausgleichsstelle der AHV (ZAS), Geneva. We obtained tabulations with the requested percentile threshold values, the income sum above that threshold, the median within each threshold along with total incomes and the total of insured persons for each year for the groups of employees, self-employed and all insured working persons taken together. Additionally, we obtained grouped tabulations with the same income brackets as in the tax statistics.

\section{Wealth Statistics}

Grouped tax data of net wealth with income brackets from zero up to CHF 10 million and above. Data downloadable from the Federal Tax Administration's web site: http://www.estv.admin.ch/dokumentation/00075/00076/00717/index.html?lang=de 


\section{Appendix B Additional Tables}

Table B.1: Synthetic control canton weights

\begin{tabular}{ccccccc}
\hline & Top 10\% & Top 5\% & Top 1\% & Top 0.5\% & Top 0.1\% & Top 0.01\% \\
\cline { 2 - 6 } ZH & 0.05 & 0.047 & 0.048 & 0.051 & 0.057 & 0.035 \\
LU & 0.12 & 0.113 & 0.121 & 0.129 & 0.139 & 0.115 \\
UR & 0.019 & 0.018 & 0.015 & 0.013 & 0.012 & 0.015 \\
SZ & 0.033 & 0.036 & 0.035 & 0.036 & 0.041 & 0.023 \\
OW & 0.001 & 0 & 0.003 & 0.004 & 0.005 & 0 \\
BS & 0.132 & 0.127 & 0.106 & 0.093 & 0.08 & 0.099 \\
SG & 0.08 & 0.088 & 0.102 & 0.105 & 0.096 & 0.137 \\
AG & 0.127 & 0.127 & 0.121 & 0.119 & 0.122 & 0.1 \\
TI & 0.043 & 0.045 & 0.039 & 0.036 & 0.035 & 0.026 \\
VD & 0.369 & 0.371 & 0.377 & 0.377 & 0.373 & 0.416 \\
GE & 0.025 & 0.027 & 0.034 & 0.037 & 0.039 & 0.036 \\
\hline \hline
\end{tabular}

Note: For each top group a separate synthetic control estimation was carried out (represented by the six columns), using all 26 cantons. The table represents the weight each canton has in the estimation of each top group's total income share. The cantons not reported in the table all have a weight of zero in each synthetic control model. 
Table B.2: Synthetic control predictor means

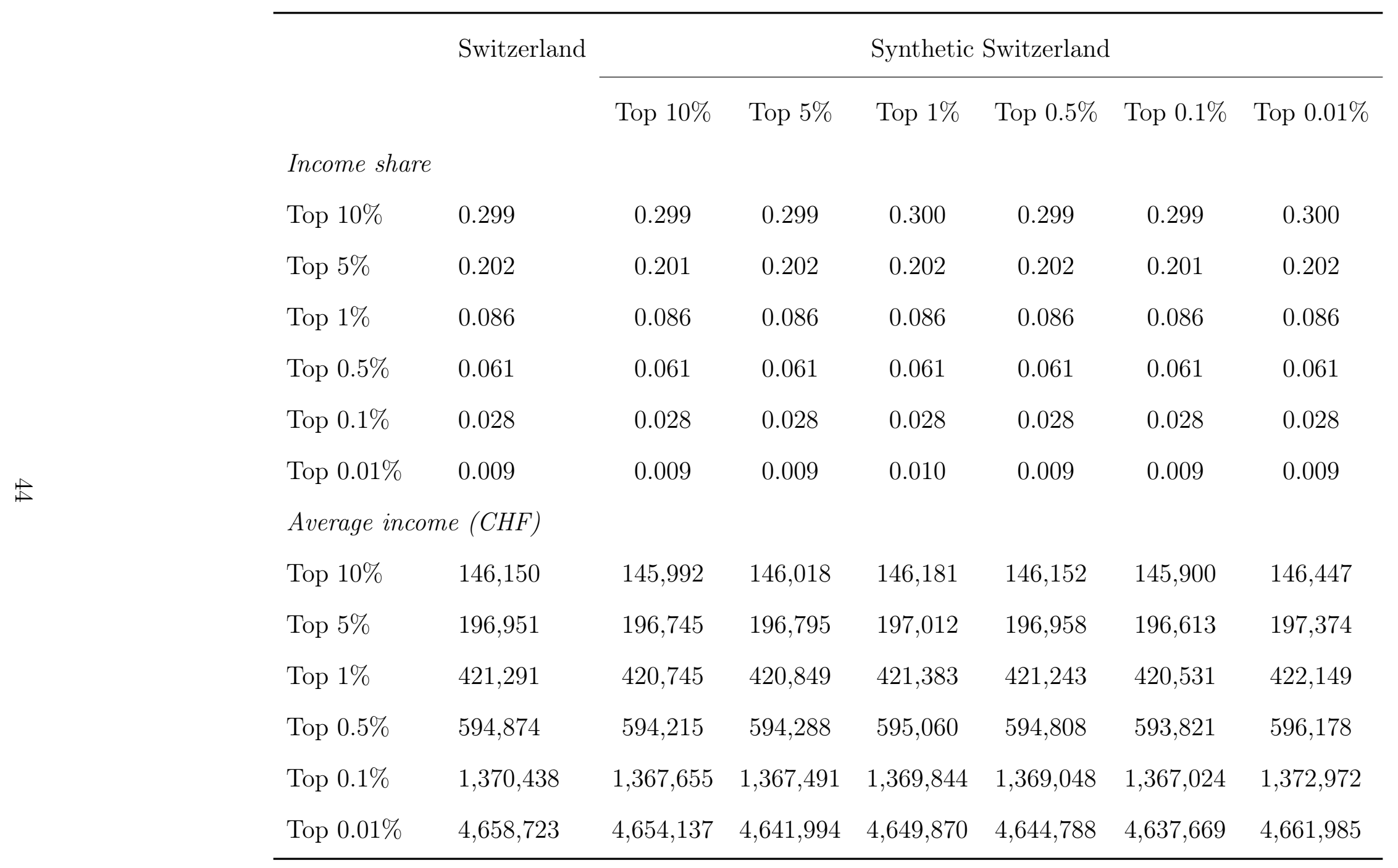

Note: The table presents the synthetic control predictors used for the estimation of each top group's income share along with corresponding means in actual and synthetic Switzerland. 
Table B.2: Synthetic control predictor means (continued)

\begin{tabular}{|c|c|c|c|c|c|c|c|c|}
\hline & & \multirow[t]{2}{*}{ Switzerland } & \multicolumn{6}{|c|}{ Synthetic Switzerland } \\
\hline & & & Top $10 \%$ & Top 5\% & Top $1 \%$ & Top $0.5 \%$ & Top $0.1 \%$ & Top $0.01 \%$ \\
\hline & \multicolumn{8}{|l|}{ Income threshold (CHF) } \\
\hline & Top $10 \%$ & 85,307 & 85,106 & 85,107 & 85,206 & 85,201 & 85,050 & 85,374 \\
\hline & Top 5\% & 109,571 & 109,306 & 109,312 & 109,390 & 109,354 & 109,149 & 109,567 \\
\hline & Top $1 \%$ & 213,191 & 212,928 & 213,039 & 213,266 & 213,232 & 212,867 & 213,560 \\
\hline & Top $0.5 \%$ & 294,934 & 294,906 & 295,074 & 295,398 & 295,320 & 294,758 & 295,981 \\
\hline & Top $0.1 \%$ & 641,495 & 644,472 & 644,759 & 644,452 & 643,641 & 642,148 & 644,892 \\
\hline \multirow[t]{6}{*}{ cr } & Top $0.01 \%$ & $2,225,218$ & $2,169,489$ & $2,173,425$ & $2,186,747$ & $2,190,349$ & $2,187,823$ & $2,202,185$ \\
\hline & Macroeconomic conditions & & & & & & & \\
\hline & GDP p.c. $(\mathrm{CHF})$ & 46,999 & 46,127 & 46,059 & 45,955 & 45,809 & 45,650 & 45,819 \\
\hline & GDP growth & 5.04 & 4.83 & 4.84 & 4.88 & 4.90 & 4.91 & 4.90 \\
\hline & Pop. growth & 1.14 & 1.17 & 1.18 & 1.21 & 1.23 & 1.24 & 1.21 \\
\hline & Unempl. rate & 1.081 & 1.261 & 1.260 & 1.237 & 1.219 & 1.198 & 1.244 \\
\hline
\end{tabular}

Note: The table presents the synthetic control predictors used for the estimation of each top group's income share along with corresponding means in actual and synthetic Switzerland. 


\section{Appendix C Technical Notes on the Construction of Top Income Data Series}

\section{The Swiss Income Tax Reform of 1995}

Before 1995, taxes were assessed upon a two-years basis and the praenumerando method was applied for levying the federal income tax. Within this system, fiscal period and assessment period do not coincide. Speaking in legal terms, the fiscal period (called Steuerperiode or période fiscale) is the time period for which the taxes are owed, while the assessment period (called Bemessungsperiode or période de calcul) is the time period during which the income was realized upon which the tax liability is calculated. The tax liability is calculated during the so-called taxation period (Veranlagungsperiode or période de taxation). So according to the praenumerando system, all incomes from the preceding two years constituted the basis for the tax liability arising in the next two-years fiscal period. ${ }^{27}$ The notion praenumerando method refers to this fact that the assessment period and the fiscal period do not coincide under such a tax system, the assessment period precedes the fiscal period (Eidgenössische Steuerverwaltung ESTV, 2003). This implies that the incomes on which the taxes payable in fiscal period 1995/96 are based were realized in the assessment period 1993/94. The tax duty for a fiscal period was thus calculated from an estimated income stream based upon past income and unless income or living conditions changed substantially, taxes were only adapted to the new income situation in the next fiscal period.

This tax system was neither very transparent nor was it easy to handle. Due to the two-years basis, citizens needed to keep all kind of records for this period. Much more important, because the tax was calculated upon past income, often a betwixt assessment (called Zwischenveranlagung or taxation intermédiaire) was arranged. This procedure was necessary as a corrective whenever the actual income of a tax period differed substantially from the one realized and reported during the assessment period, due to certain predefined reasons (such as marriage, birth of a child, or occupational changes). In such a case, taxes were re-calculated afterwards upon the effectively realized income during the tax period, thereby actually following the postnumerando taxation method.

Under the newly introduced postnumerando method, fiscal period and assessment period are identical and correspond to a legal year. The taxation period follows the fiscal period so that taxes due for a certain year are calculated upon the effectively realized income in that year. Therefore, taxation can only take place in the following year, which is why the notion postnumerando taxation is used.

The reform process, which aimed at simplifying the tax system, adopt it to the internationally common one-year based taxation, and harmonize the cantonal and municipal

\footnotetext{
${ }^{27}$ Note that the use of the praenumerando method does not include the necessity to assess incomes on a two-years basis, a yearly basis would be possible as well under such a tax system.
} 
taxation systems, ${ }^{28}$ began in the 1980s. In 1990 the change to the postnumerando taxation with the one-year assessment basis was enacted with a transitional period of several years, during which each canton could choose when to adopt the new system. ${ }^{29}$

This cantonal freedom to choose the timing to switch to the new system is the reason why during the transitional period from 1995 to 2002, there is no uniform tax data published on the Swiss level but only data on the cantonal level is available. Table C.1 shows the time schedule of the adoption of the new taxation method by canton. Basel Stadt was the only canton which had always used the one-year based postnumerando taxation method to levy the cantonal taxes, but all the other cantons had to adapt their tax systems. This transition caused a gap in the assessment of the incomes and taxes. To avoid loopholes in the tax system, transitory provisions had been enacted but these differed among cantons. ${ }^{30}$

Table C.1: Transition from praenumerando to postnumerando taxation by canton

\begin{tabular}{l|l}
\hline 1995 & BS \\
\hline 1999 & ZH, TG \\
\hline 2001 & BE, LU, UR, SZ, OW, NW, GL, ZG, FR, SO, \\
& BL, SH, AR, AI, SG, GR, AG, NE, GE, JU \\
\hline 2003 & TI, VD, VS \\
\hline \hline
\end{tabular}

\section{Choice of Tax Units: Normal and Special Cases, Capital Gains}

The tabulated tax statistics have remained stable over time so that the total number of tax units and total income are comparable over time. Nevertheless, attention has to be paid on the correct selection of these data. For the correct selection of the total of tax units, it has to be made sure that not only the normal cases but also the special cases (socalled Sonderfälle or cas spéciaux) are included. The latter include the high net wealth individuals taxed according to their expenditures (Besteuerung nach dem Aufwand or imposition d'après la dépense) and are highly relevant in the top income group. ${ }^{31}$ On the other side, the cases declared as capital gains (Kapitalgewinne) and, in later years, capital payments from pension schemes (Kapitalleistungen aus Vorsorge), are not to be

\footnotetext{
${ }^{28}$ Botschaft zum StHG sowie zum Bundesgesetz über die direkte Bundessteuer, DBG, BBl 1983 III $1 \mathrm{ff}$.

${ }^{29}$ Bundesgesetz vom 14. Dezember 1990 über die direkte Bundessteuer (DBG; SR 642.11).

${ }^{30}$ For further information on these transitory provisions see Eidgenössiche Steuerverwaltung ESTV (2003).

${ }^{31}$ Note that to be eligible for the expenditure-based taxation no labor income can be earned in Switzerland. As tax statistics do not differentiate between labor and capital income, the inclusion of these special cases makes sense.
} 
included, as these are only listed for illustrative purposes. ${ }^{32}$ They are not in fact separate tax units and including them in the total amount of tax units leads to double counting. Including them in years prior to the tax period 1989/90 does not make a big difference, as numbers are small. But as since 1990 occupational pension funds can be used to acquire real estate, the number of these cases increases remarkably. This is why the inclusion of capital payments as separate cases after 1990 leads to an over-estimate of the number of filing tax units by 2 to 3 percentage points.

The years indicated on the tax statistics refer to the fiscal period, so before the change to the postnumerando method, incomes reported do actually refer to the two preceding years. As a further consequence of the change to the postnumerando method, data on realized incomes is missing for the period preceding the change. Throughout the paper, the years in graphs and tables refer to the year in which the income was realized.

From the tax period 1995/96 onward, i.e., for incomes realized in 1993/94 and later, the tabulations available online include the normal cases only. As mentioned above, the exclusion of the special cases leads to an underestimation of top income shares and therefore the data have to be requested from the Federal Tax Administration. This means, that also for further updates of the series one may have to request the data.

\section{Tax Units}

Everyone legally residing permanently in Switzerland and who has completed the legal age of 18 years (respectively 20 years prior to January 1 of 1996) is subject to the Direct Federal Income Tax and has to fill a tax return. Married and officially registered couples (in act since January 1 of 2007) are subject to joint tax liability, therefore they show up as one single case in the tax statistics.

\section{Tax Units and Incomes not Covered}

Individuals and incomes missing in the tax statistics are the reason why we need to estimate a total income denominator as well as the total number of tax units in order to construct the relative income shares. The statistics do only report cases that were actually taxed, i.e., when taxable income was high enough to excess the amount of exemption of the federal income tax. The schedule of the federal income tax is very progressive but with a low exemption level, therefore not many low-income tax units are missing.

Apart from this group, other groups possibly not showing up are those taxed at the source, international organization's staff and real non-filers. Last but not least some individuals may show up in the statistics but corresponding incomes reported are too low due to tax evasion. In the following, each of these groups is discussed.

\footnotetext{
${ }^{32}$ In the publication by Dell et al. (2007) these cases are included in the total number of tax units.
} 


\section{Individuals Taxed at the Source}

Foreign nationals officially living in Switzerland but with a yearly or any other temporary resident permit only, as well as non-residents earning income in Switzerland, e.g., crossboarder commuters, are taxed at the source and do thus not fill a tax return. As the focus of the paper lies on the income distribution among Swiss residents, the latter cases are of no further concern.

Foreign residents with a temporary permit are required to fill a tax return ex post only if their total yearly income exceeds a certain threshold (around CHF 120000 in 2012), in which case they will then be included in the tax statistics. As this threshold lies below the top 10\% income threshold, this implies that these individuals and their incomes nevertheless do appear in the statistics. As for those taxed at the source but falling below this threshold, we can only make an educated guess about their incomes. We start assuming that the distribution of incomes for legal foreign residents should be somewhat similar to the one of permanent residents (although one could expect some sort of wage discrimination against immigrants in some industries). Then there are the mentioned income earners at the top, which are not taxed at the source while special groups such as foreign students are subject to taxation at the source. The latter typically earning below-average incomes and the former having high incomes by definition, leaves us with a pool of below-average income earners not covered in the tax statistics. With regard to the extent to which taxation at the source is present, data from several cantons show a mixed picture, depending mainly on the geographical location of the canton. In all the cantons, however the number of individuals taxed at the source has been increasing over time, especially since the mid 1990s. By 2010 it reached over $20 \%$ of the population in some of the cantons exposed most to cross-border commuters, such as the cantons Schaffhausen (SH) and Basel-Country (BL). In Zurich (ZH) and Basel-Stadt (BS) the fraction lies around $15 \%$ of the population and it is substantially lower in cantons with no boundaries with surrounding countries, such as in Bern (BE; 4\%), or Aargau (AG; $7 \%)$.

\section{International Organizations' Staff}

International organizations' staff based in Switzerland is exempted totally or partially from personal income taxation. ${ }^{33}$ No less than 24 organizations residing in Switzerland benefit from tax exemptions for their whole or part of their staff, all of them except for two located in Geneva (GE). Geneva does indeed have the lowest rate of filers, reaching an average of only $76 \%$ compared to the Swiss average of $86 \%$ for the period covered, reflecting the high percentage of residents who are not subject to personal income tax.

\footnotetext{
${ }^{33}$ At some of the organizations benefiting from a special treatment, Swiss citizens are not subject to the tax exemption.
} 
True Non-Filers

Even though it is the law to fill and hand in a tax return every year, there are people who fail to do so. In cases where individuals do not accomplish with their duty to fill out a tax return within due time, the tax administration attributes these individuals an income based on former tax returns and on employer's information about the income, so that these individuals do show up in the statistics, but their income is measured with some error. However, according to information from cantonal tax administrations, there are not many of these cases (around $4 \%$ for the canton of Bern in 2009).

\section{Individuals Evading Taxes}

While there are legal reasons why someone would not appear in the tax statistics, there is of course also the case of tax evasion. But while tax evasion has an effect on total reported income, its effect on the number of total tax returns handed in is much smaller. While it is possible not to declare certain incomes, it is much more difficult not to appear in the cantonal tax registers and not to fill out a tax return at all.

\section{Estimation of Total Income}

As the total income reported in the tax statistics does not take into account all incomes actually earned in a given period, it is necessary to accurately reconstruct total income, which is then used as denominator to calculate the top group's income shares.

For incomes simply not disclosed by the statistics as described above, we assume that their incomes are below average income. Following the approach adopted by Dell (2007) we assign the tax units not covered in the statistics $20 \%$ of average personal income reported in the tax statistics, i.e., $20 \%$ of per capita Reineinkommen. This seems a reasonable assumption and this method guarantees a high level of comparability with the existing series so that the update should not cause a break in the series.

In addition to estimate total personal income taxed one would like to relate these values to another, exogenous measure of total income in the economy, such as net national income reported in the national accounts. The ratio of reported tax income to the net national income starts at around $72 \%$ in 1981 but then falls over time to a low of $60 \%$ in 2006, rising again afterwards. Similarly, our income denominator containing the imputed incomes for the non-filers fluctuates somewhere between $65 \%$ and $74 \%$. Even though the definitions of total income have changed over time due to revisions of the national accounting system, our results are in line with those reported by Dell et al. (2007). This remaining gap can at least partly be explained by tax evasion.

\section{Estimation of Total Tax Units in the Country or Canton}

To calculate the top income groups as percentage shares accurately, the same argument as for the total income applies: as not all tax units are contained in the tax statistics 
we need to calculate the total of tax units in the country. These have to be constructed either from census data or register data.

Dell et al. (2007) use decennial census data, which covers the whole 20th century. By linear interpolation between two consecutive censuses, the authors construct annual series for the total number of adults (which for their covered time span is 20 years and older), the total number of married adults and the total number of tax units, defined as the total number of adults minus half the married adults, for each year.

For the present study, a slightly different approach is adopted. As for the time span of our study register data on the federal as well as on the cantonal level are available on a yearly basis, we make use of this detailed information. This has the advantage, that migration shocks and population trends are better represented in the data. Especially migration shocks remain probably disregarded when interpolating linearly over a time span of 10 years. Another reason why we do not follow the linear interpolation approach between census years is of a practical nature: the decennial census has been abolished after 2000 and is now replaced by a representative population sample combined with register data. Furthermore, the use of register data makes it easy to account for the reduction of the legal age from 20 to 18 years by January 1 of 1996 . This reduction of the legal age led to an increase of the total amount of tax units in the country and by not accounting for this change one would overestimate the fraction of tax filers. So up to 1995 our total tax units refer to the total adult population minus half the married individuals aged 20 and above, while from 1996 onwards the same population groups but aged 18 and above are used.

When comparing the series of tax units constructed by Dell et al. (2007) using linear interpolation and those stemming from register data on Swiss level, two effects can be observed. On one hand, estimation of total population numbers by linear interpolation leads to slightly higher numbers of total individuals than those reported in register data for some periods, namely the 1980ies and the beginning of the 2000s (a period not covered in the reference study by Dell et al., 2007). This would lead to a higher number of total tax units. On the other hand, the interpolation of married adults leads to higher values than those reported in register data (for some reason the decennial numbers from the census are higher than those from registers for corresponding years). A higher number of married individuals has a dampening effect on the total of tax units. As the effects go in opposite directions, it is a priori not clear which one predominates. A comparison of total tax units shows that for the time span 1981/82-1991/92, the total of tax units is slightly higher when using register data than when interpolating. The effect on the fraction filing and non-filers, respectively, remains small and lies between 0.9 and 2.25 percentage points. Note however, that differences in the number of total tax units and the fraction of non-filers also lead to a slightly different total income denominator. But again, the differences are small and, most important, are even smaller when it comes to 
the estimation of top income shares.

\section{Special Notes on the Calculations at Cantonal Level}

In principle, wherever possible the same procedures were carried out on cantonal level as on the Swiss level. Yet the lack of data availability makes it sometimes necessary to adopt a slightly different method. For the total number of tax units on cantonal level, the number of married individuals is linearly interpolated, as no register data on the married individuals by age are available on cantonal level. A comparison of interpolated vs. actual yearly register data on the federal level shows that the interpolated series for the married individuals lead to estimates below the values reported from the registers (see above). Therefore we slightly overestimate the total of tax units and the fraction of non-filers on cantonal level, which in turn has a somewhat dampening effect on the total income denominators on cantonal level.

When relating the total income denominators on cantonal level to the cantonal net revenues, one has to be careful when it comes to interpretations of the values. First, cantonal net revenues reported in national accounts may suffer from some measurement errors, and second because on the cantonal level taxable income was probably not generated within the canton where it is taxed. This is so because it is possible to work in one canton and to live in another, but income is always taxed in the canton of residency.

\section{Estimation of the top income shares using Pareto interpolation}

The estimation of top income shares follows the approach adopted by Piketty (2001) and Dell et al. (2007). First, the local Pareto parameters $b$ and $k$ corresponding to the lower $s$ bound of each income bracket in the tax statistics are calculated

$$
b_{s}=\bar{y}_{s} / s
$$

where $y_{s}$ is the average income per tax unit above the threshold $s$. The original Pareto distribution coefficient is then $a_{s}=b_{s} /\left(b_{s}-1\right)$. The parameter $k_{s}$ is defined as

$$
k_{s}=s \cdot p_{s}^{\left(b_{s}-1\right) / b_{s}}=s \cdot p_{s}^{1 / a_{s}}
$$

where $p_{s}=1-F(s)$ denotes the share of tax units with income larger than or equal to $s$. We use the local parameters corresponding to the income bracket $s$ where the population share $p_{s}$ is closest to the population share of interest $\rho$, e.g. closest to $10 \%$ of total tax units $N$. The income threshold $T_{\rho}$ to belong to the top percentile $\rho$ is then given by

$$
T_{\rho}=\frac{k_{s}}{\rho^{\left(b_{s}-1\right) / b_{s}}}=\frac{k_{s}}{\rho^{1 / a_{s}}}
$$


The average income per tax unit above this income threshold, $\bar{y}_{\rho}$, reads

$$
\bar{y}_{\rho}=T_{\rho} \cdot b_{s}
$$

Total income for each top group then is $y_{\rho}=\bar{y}_{\rho} \cdot(100-\rho) \cdot N$. Total income of each top group divided by the total income denominator yields the income share of each group.

\section{Estimation of Swiss Top Shares for the Missing Years}

In order to estimate the values for the missing years we extrapolate them from the existing cantonal series using linear fixed effects OLS estimation. In order to make use of the maximum number of data points available, several linear regressions are carried out, always regressing the series for Switzerland on those of one or several regions as defined above. Table C. 2 shows the different models estimated for each year. Using linear forecasting, the missing values for the Swiss series are extrapolated from the cantonal series. The last row of Table C.2 indicates the years for which each model was used to obtain the extrapolated values.

Table C.2: Regression models used for estimation of Swiss top income shares

\begin{tabular}{|c|c|c|c|}
\hline & \multicolumn{3}{|c|}{ Model } \\
\hline & $\mathrm{I}$ & II & III \\
\hline Independent variables: & BS & $\mathrm{BS}$ & $\mathrm{BS}$ \\
\hline cantonal top shares & - & $\mathrm{ZH}$ and $\mathrm{TG}$ & $\mathrm{ZH}$ and $\mathrm{TG}$ \\
\hline & - & - & 20 cantons \\
\hline Model used for extrapolation in... & $1995-1998$ & $1999-2000$ & $2001-2002$ \\
\hline
\end{tabular}

Dependent variable: top p percent group's income share at federal level 